\title{
O CATOLICISMO. DIREITO E A POLÍTICA NO ESTADO BRASILEIRO
}

\author{
CATHOLICISM. LAW AND POLITICS IN BRAZILIAN STATE
}

Antonio Augusto Machado de Campos Neto*

\begin{abstract}
"Como o poder corrompe, a demanda da sociedade por autoridade moral e caráter aumenta à medida que aumenta a importância da posição"

John Adams, segundo Presidente dos Estados Unidos da América
\end{abstract}

"Deus nos concede, a cada dia, uma página de vida nova no Livro do Tempo. Aquilo que colocarmos nela, corre por nossa conta"

Francisco (Chico) Xavier

"No Jornalismo, o importante é criar memórias"

Geneton Moraes Neto

"Aqui, a Constituição é a minha Bíblia; o Brasil, minha única Religião (...)”

Ministra Cármen Lúcia Antunes Rocha

"Como a Filosofia Jurídica quer conceber o Direito em sua universalidade. Deve harmonizar a inteligência do Direito com a concepção do mundo. Do ser em geral”.

Giorgio Del Vecchio

Resumo:

Catolicismo é a Religião dos cristãos que reconhecem o Papa como autoridade máxima, que se confirma e expande por meio dos sacramentos, que venera a Virgem Maria e os santos, incluso Maria Madalena, e aceita os dogmas como verdades incontestáveis e fundamentais. Dentre todos destaca-se a missa como o ato litúrgico mais importante. Nascido na Palestina por meio de comunidades primitivas chamadas de Corpo de Cristo, em processo secular desde o reforço e da conversão do imperador romano Constantino I e de sua mãe, a imperatriz Helena, o Catolicismo, apêndice do Cristianismo, abrange $1 / 3$ da população mundial. O fundamento sistêmico na aderência do Povo católico é baseado no Codex das Escrituras e do Clérigo, uma vez considerar o Papa o representante de Jesus Cristo.

\footnotetext{
Ex-Chefe do Serviço Técnico de Imprensa e Propaganda da Faculdade de Direito da Universidade de São Paulo. Bacharel em Direito pela Faculdade de Direito da Universidade de São Paulo. Bacharel em Jornalismo pela Faculdade de Comunicação Social Cásper Líbero.
} 


\begin{abstract}
Suas igrejas são espalhadas em todo o planeta, incluso na China. A Bíblia cristã, em seus 76 Livros e 2 mil leis bíblicas, oriunda e parte da Bíblia hebraica é o Livro de orientação, estudo e pesquisa dos católicos. O Direito brasileiro, embora o Estado seja laico, se embasa na interligação do Direito Canônico e Direito Romano, principalmente em áreas de visão paroquial religiosa no âmbito do Direito Civil, Direito Consuetudinário, Direito Comparativo e Direito Penal e Processual. A Política brasileira encontra-se embaraçada, repleta de controvérsias, enfatizando os crimes de corrupção postergados há anos no País.
\end{abstract}

Palavras-chave: Palestina. Lei mosaica. Direito Canônico. Concílio de Niceia. Cânon das Escrituras. O Direito brasileiro. A situação do Brasil em 2016.

\begin{abstract}
:
Catholicism is the religion of Christians who recognize the Pope as the highest authority confirmed through the sacraments; venerates the Virgin Mary and the saints, included Mary Magdalene, accepts dogmas as indisputable and fundamental truths, and considers Mass as the most important liturgical act. Born in Palestine through primitive communities called the Body of Christ in secular process from the building and conversion of Roman Emperor Constantine and his mother, Empress Helena, Catholicism, considered the Christianity appendix, covers $1 / 3$ of the world population. Systemic foundation in Catholic People's grip is based on Codex of Scripture and the Clergyman, once considered the Pope the Jesus Christ's representative. Churches are scattered around the world, included in China. The Christian Bible, with its 76 books and 2,000 biblical laws, partially derived from the Hebrew Bible, is the Catholic guidebook. Brazilian law, although the State laicity is grounded on interconnection of Canon and Roman Laws, especially in areas of religious parochial view under the Civil Law, Customary Law, Comparative Law and Criminal and Procedural Law. Brazilian policy has been embarrassed, full of controversies, due to postponed bribery crimes in Brazil.
\end{abstract}

Keywords: Palestine. Mosaic Law. Canon Law. Council of Nicaea. Canon of Scripture. Brazilian Law. Situation in Brazil in 2016.

\title{
I. O Catolicismo
}

1. Introdução

Durante muitos séculos os judeus viveram na Palestina, geograficamente no extremo oriental do Mar Mediterrâneo; todavia, já havia bastante tempo que não eram verdadeiramente independentes, porque no século VI a.C. foram conquistados pelos babilônicos, por meio bélico, coordenado pelo Rei Nabucodonosor e época de Daniel por cerca de 50 anos: um período difícil e traumático conhecido como o exílio babilônico.

A História do Povo hebreu, a princípio cronológico, cita-se a dominância pelos persas que construíram um império robusto em direção ao Leste. Logo em seguida, os selêucidas dominaram o Povo judeu, tratando-se de uma dinastia fundada com 
consequência finalizada das famosas e históricas conquistas do general Alexandre III, o Grande, da Macedônia.

O Povo judeu se rebelou contra os selêucidas no século II a.C., mas antes no século I a.C. foi conquistado pelo general Pompeo, de Roma. Daí em diante, a Palestina se torna parte integrante do Império romano. O último Livro do Pentateuco, denominado Deuteronômio, conhecido como a Torah contém escritos da época do exílio babilônico do século VI a.C. Dentre os históricos narrados, o mais famoso é o do arameu errante Abraão que trocou a cidade suméria de Ur (pertencente ao Iraque moderno) pelas terras do Rio Jordão.

A citação é lembrada porque Deus fez um pacto com Abraão, prometendo que seus descendentes se tornariam poderoso Povo que, ricamente e de maneira protegida, viveria em terras israelenses. Todavia, sua família emigrou para o Egito, onde se tornou numerosa, vindo a ser "Israel" que significa "Os Judeus" ou "Aqueles que lutam ao lado de Deus".

No Egito foram escravizados; porém, o Deus Único os salvou no grande evento intitulado $O$ Exodo, contemplado e descrito no Segundo Livro que também leva este nome, Livro do Exxodo. E não apenas o Deus Único os tirou do Egito, levando-os à Terra Prometida, Canaã (Kenáan), fundada e colonizada pelos seus antepassados como, também, lhes deu a Lei: um código de normas jurídicas, rezado à obediência e adorar um Deus Único. A viver civilizadamente em uma sociedade, resumida nos Dez Mandamentos, ${ }^{1}$ escritas indiretamente por Ele, em tábuas de pedra, entregues a Moisés que as registrou de próprio punho.

Embora a morte de Moisés seja descrita no final do Deuteronômio, os judeus acreditavam que ele fosse o Autor dos Cinco Livros da Torá; daí o nome Pentateuco, a saber: Gênesis (Bereshit), Exodo (Shemót), Levítico (Vayikrá), Números (Bamidbar) e Deuteronômio (Devarim).

Enfatiza-se que Moisés, sempre disposto a cumprir todas as determinações ditadas pelo Eterno, era príncipe no Egito, salvo das águas pela filha do Faraó, filósofo espiritualista, engenheiro, cumprindo a ordem do Senhor na construção divina do tabernáculo e escritor. Um guerreiro de pura força divina e sempre acompanhado pela sua dedicada mulher, Tsípora, com quem teve dois filhos, sendo o primogênito Guershom.

\footnotetext{
Alguns especialistas concordam atualmente que a versão mais antiga dos Dez Mandamentos é a que consta no Capítulo V do Deuteronômio, Livro este publicado pela primeira vez em 622 a.C. e nesse ano, segundo o Antigo Testamento, um texto conhecido simplesmente como o Livro da Lei ou Livro da Aliança foi descoberto no interior do Templo de Jerusalém e levado até Josias, Rei de Judá. Em consonância com a Bíblia, essa obra seria a compilação original das leis dadas por Deus a Moisés e que teria ficado esquecida por séculos e de acordo com a maioria dos pesquisadores, essa obra é o livro bíblico, hoje conhecido como Deuteronômio. Nele, vários discursos atribuídos a Moisés.
} 
Tsípora era uma das sete filhas de Jetró (Reuil), profeta e filósofo, chefe de Midiã, aonde Moisés escolheu se deter ao sair do jugo egípcio.

A história subsequente dos judeus foi narrada em outros livros que, por sua vez, recontavam como, sob uma sucessão de reis, tinham aderido ou se afastado da fidelidade à Lei e da adoração a um Deus Único que, consequentemente, enviou série de profetas para trazer Israel de volta à verdadeira Lei.

Esses livros formaram a base das Escrituras judaicas embora, na época de Jesus, não houvesse uma versão oficial de quais deles eram autorizados e quais não o eram, lembrando que alguns deles constituiriam parte do que os cristãos denominariam como a coletânea dos Livros do Velho Testamento.

Os judeus acreditavam que a sua História estava intimamente ligada a Deus; que veementemente tinham sido eleitos por Ele como um Povo Especial. Um Povo que agia corretamente por intermédio da Lei e dos Profetas; estes, atuavam em seu benefício, principalmente em momentos difíceis como $O$ Exodo.

Um Povo forjado a permanecer vagando por 40 anos pelo deserto, sustentado por alimento vindo diariamente dos Céus, manah; dentre eles, os representantes das doze tribos, em especial os levitas. Eram comandados por Moisés e assistidos pela sua mãe, Iochébed, e seus irmãos Aarão e Míriam, além do sobrinho guerreiro Josué, seu sucessor, que fora casado com Ana, de descendência egípcia.

Após a morte do profeta Moisés, aos 120 anos de idade, Josué, filho de Num, prossegue a determinação do tio, liderando o Povo escolhido e comandando o Exército hebreu na primeira batalha solo, no Vale de Ayyalon, nas cercanias da mais antiga cidade da Antiguidade pela arquitetura, Jericó, chamada de Reino Invencível, durante o Reinado do Rei Marek (o primeiro dos 31 Reis derrotados por Josué e os filhos de Israel da Banda de aquém do Jordão; Josué: 12,7) e da Rainha Kalesi, localizada entre Jerusalém e Tel Aviv.

As ruínas desta cidade podem ser visitadas até hoje e apreciar que Jericó era amuralhada. Em seu interior, o sítio apresenta evidências físicas dos locais de rituais primitivos e cruéis - como a oferenda de virgens e recém-nascidos aos deuses do Paganismo -, cujo propósito, dentre eles, o de vitórias militares. As mandingas também já eram executadas em cerimônias dos deuses pagãos.

Os judeus também acreditavam que Deus tinha um pacto de tolerância, segundo o qual as terras da Palestina pertenciam exclusivamente a eles, sendo a responsabilidade, neste pacto, a de sempre manter a Lei. A marca ditada pela obediência à Lei era a de Povo circuncidado, sendo a referência "circuncidado" e "não-circuncidado" termo de diferenciação em ser judeu e não-judeu, respectivamente.

Havia judeus fora da Palestina que, na verdade - na época de Jesus Cristo -, existia mais judeus fora do que dentro da Palestina e por volta do ano 30 d.C. Jesus de 
Nazaré, um pregador da Galileia - com reputação de realizar milagres - fora executado nos arredores de Jerusalém. Lembrando que, para eles, Jesus se tornara um Espírito inconveniente, causando problemas no Templo de Salomão, incluso ao sumo sacerdote, Caifás, que não podia, dado o cargo, tolerar confusões públicas, principalmente durante o período da Páscoa, Pêssach, quando inúmeros peregrinos se concentravam em Jerusalém, Cidade conhecida como a Terra de David.

Nos anos 30 d.C., o pregador judeu, o último de uma linha de personalidades religiosas carismáticas, como David, é executado pelas autoridades do Império romano e seus seguidores se espalharam assustadoramente, sendo que os cidadãos do mundo não lhes dá atenção e, em pleno século XXI, aproximadamente $1 / 3$ da população mundial cerca de 3,6 bilhões - são considerados seguidores daquele pregador!

Há um fato de suma importância não despercebido pelos futuros cristãos: Jesus nasceu junto ao início do Império romano, época em que Roma, a Cidade Eterna, expandia gradativa à sua força tanto em áreas geográficas desenhadas ao seu redor quanto além da Península ibérica e que tinha sido até recentemente uma República, derrotando rivais como Cartago e os Estados-gregos, além de controlar a linha costeira do Mar Mediterrâneo e a Gália, conquistada pelo imperador Júlio César. Lembra-se que o primeiro e verdadeiro imperador romano foi o sobrinho de César, Otaviano.

À morte de César, 44 a.C., houve guerra civil vencida por Otaviano, enfrentando e derrotando o cônsul romano Marco Antonio e a Rainha egípcia Cleópatra, de origem grega, sua amante e mãe de um filho com o general, Alexandre Hélio. Época em que se adicionou o Egito aos domínios romanos e lembrando que Cleópatra, filha de Ptolomeu XII, já tinha outro filho primogênito com Júlio César, Cesarion. Astuta e intelectual Cleópatra foi a última das séries de faraós no Egito; porém, imortalizada.

Otaviano, assumindo o nome de César Augusto, essencialmente criou o Governo e todas as estruturas do Império romano, embora se recusasse a chamar a si mesmo de qualquer outro título além de princeps, significado de "o primeiro". Observador inigualável e cuidadoso em manter o perfil da velha República como, também, o Senado retendo o controle nominal do Estado.

Todavia, eleições para o Senado foram articuladas por Augusto e os cargos preenchidos por homens de sua absoluta confiança e ligados aos seus próprios interesses. Embora o Senado tenha permanecido, o imperador governava e isso quer dizer que, sob alguns dos mais destemperados sucessores, o cargo de senador poderia ser um posto elevado, mas muito perigoso.

O imperador Augusto também reorganizou o serviço público, proclamou novas leis, patrocinou novos trabalhos artísticos e apoiou a Religião tradicional romana, além de pôr a antiga República em uma base fortemente imperial. Sob César Augusto, toda a Espanha e a França modernas foram dominadas assim, também, os Balcãs e a 
África do Norte. O mosaico de conquistas romano é inacreditável e fantástico, deixando um legado de sabedoria popular até hoje vivida pelos povos conquistados.

O imperador era muito mais que simplesmente "o primeiro" entre os iguais. No ano 12 d.C. Augusto seguiu o exemplo de Júlio César e se tornou pontifex maximus, o primeiro sacerdote da tradicional Religião romana. E se constituiu, assim, uma união oficial entre o Estado e a Religião, ambos personificados em um único homem: o imperador.

\section{Os primeiros cristãos}

Antes de sua condenação, morte e ressurreição, mister se faz lembrar que Jesus Cristo usava imagens do Velho Testamento, identificando-se como "o Filho do Homem" ou "o Filho do Sol" e no Livro de Daniel esta era uma imagem gloriosa que, por sua vez, representava o Povo de Deus perante o seu trono. Todavia, Ele também deu claras evidências de que era o Servo Sofredor, profetizado em Isaías.

Um de seus discípulos, Judas Iscariotes, o traiu. Espiritualmente, em consonância à Filosofia Espírita, Teoria Reencarnacionista - várias passagens pela Terra no intuito de evolução -, foi dificílimo desempenhá-la, uma vez ter lembranças (ideias inatas) dessa passagem, neste episódio, principalmente o de ter de entregá-Lo, oriundo da Ordem de Deus e à evolução da História da Humanidade.

Judas Iscariotes agiu junto às autoridades religiosas que $\mathrm{O}$ prenderam após a meia-noite no Jardim Getsêmani, quando foi julgado de série de acusações, além de O apresentar, na manhã seguinte, ao governador romano Pôncio Pilatos, que ordenou a sua crucificação.

Ao encontro da Filosofia Espírita, tudo isso havia sido premeditado como, também, ordenado pelo Salvador, uma vez ter se referido que havia chegado a sua hora e que tenha tentado exatamente em três avisos alertar seus discípulos e amigos de que seria rejeitado (por Pedro em três vezes) e crucificado. À noite, anterior à sua morte, ofertou vinho e pão a todos os apóstolos; se trata de uma parte integrante das tradicionais celebrações da Páscoa judaica como, também, lhes dado significado inteiramente novo: eram seu corpo e sangue!

Todos os dados acima, a maioria dos quais não é contestada pelos acadêmicos modernos, indicam que possa haver mais fatos nessa vida solitária que inicialmente imaginamos, por meio da tradição e da palavra contada: se o Deus de Israel estava se tornando Rei por meio de Jesus; então quem era Jesus? De onde Ele obteve essa evidente autoridade em palavra e fato? E por que Ele aparentemente orquestrou sua própria morte? O que teria acontecido no terceiro dia após a sua morte? 
Cristãos são aqueles que estão devidamente convencidos de que a História não acabou aqui; mas que Jesus ascendeu do túmulo pelo poder de Deus. Todos os Evangelhos terminam com essa dramática declaração da Ressurreição: Jesus voltou a Deus no Céu, onde está sentado em glória ao lado direito do Pai Criador, conforme o Credo.

O Credo anterior, ou confissão, entre os primeiros cristãos era interpretado como "Jesus é o Senhor" e eles divulgaram esta assertiva como "boa-nova" por todo o mundo. Portanto, os primeiros cristãos eram judeus que, por sua vez, acreditavam que Deus tenha ressuscitado Jesus dos mortos provando, desta maneira, sua divina mensagem. Todavia, o Livro de Atos (6:1-6) sugere um grupo mais complexo ao descrever uma disputa entre os helenistas e hebreus.

Mas quem eram os helenistas? Eram judeus da Diáspora, ao invés de procederem da Palestina? Eram judeus cristãos que queriam que o grupo se afastasse mais da principal corrente do Judaísmo? Ou eram os não-judeus, ou seja, os gentios que também acreditavam em Jesus?

Ninguém sabe!

Na época da Ressurreição (Reencarnação) a comunidade cristã era parte da comunidade judaica, cuja menção do dia a dia da primeira, a cristã, relata que ela se encontrava frequentemente no Templo mas, também, formava um grupo distinto e a referência em dividir o pão; provavelmente sugere não uma cerimônia formal, porém o ato de realizar refeições em conjunto. E nos dias de hoje compartilhar uma refeição se trata de uma forma de criar laços sociais, de amizade e um sentido de identidade de grupo.

Enfim, esse era especialmente o fato na Antiguidade; enfatiza-se que no Judaísmo o evento anual mais importante para uma família era o da refeição da Páscoa, Pêssach. Dessa maneira, a comunidade cristã se tornou uma Igreja, cuja palavra, igreja, de origem grega, significa assembleia e no Novo Testamento é geralmente usada às referências de comunidades individuais. Havia uma Igreja em Jerusalém, outra na Antioquia e assim por diante.

Durante todo o século I, os cristãos se reuniam não em edificações construídas para essa finalidade; todavia, esses encontros se realizam nas casas umas das outras de seus moradores adeptos ou em casas convertidas. Nada se sabe até hoje o que acontecia em Jerusalém. O Livro de Atos e o Livro de Lucas (apelido de Lucano) afirmam que, após a Ressurreição de Jesus, todos os seus discípulos permaneceram em Jerusalém, onde receberam o Espírito Santo, fato este que acarretou a formação da primeira comunidade cristã. O Livro de Mateus narra que, após a Ressurreição, todos os discípulos voltaram para a Galileia e no Evangelho de João está descrito que eles retornaram às suas vidas normais, dentre elas a de pescadores. Se eles de fato trouxeram Sua Mensagem à Galileia, nada se sabe ao o que se seguiu. 
O Livro de Atos sugere que o Cristianismo se dispersou por toda a Palestina, não estava mais concentrado em um lugar único; como resultado, o das perseguições contra os cristãos em Jerusalém. Eles fugiram, carregando a Mensagem recebida. O Cristianismo tem como mola-mestra a ideia da Filosofia da Fé e a fé dos primeiros cristãos foi passada ou transmitida oralmente. O movimento crescia assustadora e surpreendentemente, mas mostrava sinais vagarosos, mostrando que essa forma de comunicação de ensinamentos não seria o suficiente à meta atingida, mesmo porque eram insistentes e disciplinados, fortes e corajosos. A ideia foi a de começar a escrever, vindo à tona os primeiros escritos de cristãos como é o exemplo de Paulo: as Cartas de Paulo, enfatizando a Carta aos Gálatas. $^{2}$

Enfim, série de religiões surgiram e elas são fundamentais, por meio da crença em um ou em vários deuses e deusas. O Judaísmo, o Cristianismo e o Islamismo são religiões monoteístas, porque creem em um Deus Único, Eterno, Criador e TodoPoderoso. São religiões que se desenvolveram no Oriente Médio e que compartilham muitos rituais, festivais, narrativas, mitos e ritos. O maior exemplo é a Bíblia hebraica que se tornou parte integrante da Bíblia cristã, ao passo que Jesus Cristo, o fundador do Cristianismo, é considerado um profeta pelos muçulmanos em parâmetro aos cristãos que O consideram o Filho de Deus.

\section{Compromisso religioso}

A Religião é praticada em quase todas as comunidades humanas, inclusive em lugares onde fora formalmente proibida: indivíduos continuaram a cultuá-la secretamente e sempre com risco pessoal.

E o que se deve a isso?

2 As cartas de Paulo eram de conteúdo tenso; na Carta aos Gálatas escreveu que após o Concílio de Jerusalém, considerado o primeiro Concílio do Cristianismo, Pedro veio para Antioquia e "eu me opus a eles, cara a cara, pois ele se manteve auto-condenado", dizia em um dos trechos. Agindo sob a influência de Tiago, Pedro estava agora se recusando a se alimentar junto com os gentios. Assim dizia outro trecho. E a maior parte da Carta aos Gálatas diz respeito a um problema desta forma assim relacionado. Muitos seguidores da Igreja gálata tinham aparentemente se convencido de que era essencial ser circuncidado, isto é, tornarse judeu antes de se tornar cristão. Paulo se opunha a eles e insistia que "para Jesus Cristo ser ou não-ser circuncidado não tinha nenhum significado. A única coisa viva que contava era a fé que funcionava pelo mundo". É difícil discernir o grau em que a Igreja do século I se dividiu em relação a esse tema e às questões a ele relacionadas. Alguns historiadores argumentam que as divisões eram muito maiores do que isso; que poderiam parecer, a partir de uma leitura de evidência e que havia um cisma completo entre Paulo e os pró-gentios de um lado, e Pedro e Tiago e o partido pró-judaísmo do outro; e que, como o partido de Paulo venceu, os documentos que permaneceram foram escritos de uma maneira tendenciosa para dissimular essa situação. E é claro que tal visão mais do que levanta a questão de dúvidas, mesmo porque não há outra evidência, além dos documentos que sobreviveram. 
Premissa final: A Religião oferece ao indivíduo um significado de vida além da realidade, proporcionando, assim, explicações transcendentais para ocorrências das mais misteriosas. Indivíduos não-espirituais, às vezes, consideram a Religião como uma fuga da realidade ou, ainda, uma forma de escapar de um mundo sombrio.

Todavia, as pessoas religiosas provavelmente replicam que a Religião é um canal elucidativo do explicar o fato do milagre da vida e de um modo que a Ciência não consegue. Incluem-se neste tópico homens que dão crédito às visitas extraterrestres, mediante quadros apresentados aos olhos da Humanidade, como é o caso e exemplo dos moais da Ilha de Páscoa, Chile. São gigantescos monumentos esculpidos e enfileirados em linha linear, independentes de perfis e que contemplam atentamente as salgadas águas límpidas do Oceano Pacifico. A sensação é a de se estar na presença de uma inteligência extraordinária, lembrando que são escultores e arquitetos que vieram de uma mesma Escola incompatível aos homens dos séculos passados. Magníficos monumentos de peso astronômico de pedras monolíticas que ali estão há milhares de anos e há centenas de outros espalhados pela bela ilha.

Outro exemplo, Stonehenge (Grã-Bretanha) construído de pilares com peso de 50 toneladas, no intuito de reverenciamento aos antepassados a 2.750 a.C. Stonehenge possui uma história apagada de uma Religião perdida amoldada pelos bretões - época do Rei Arthur - que estudavam os ciclos solar e lunar. Eles eram adoradores do Sol e da Lua.

$\mathrm{Ou}$, ainda, as três pirâmides no Planalto de Gizé, Egito, guardadas pela Esfinge, uma acrópole sagrada; dentre elas, a do faraó Queóps também reverenciando a vida após a morte. Por último, as estátuas merines (pedras) da Córsega (1.500 a.C.) as Filitosas na região Sudoeste, aonde várias delas foram localizadas. As Linhas (diagramas) de Nazca, Peru; as Pedras de Karnac, na Bretânia e os templos de Borobudur, Indonésia devem ser computados como obras de homens de extraordinária inteligência, incompatíveis às suas épocas.

As religiões oferecem a seus seguidores maneiras de se entender a vastidão e a complexidade do Universo; ademais, criam o sentimento de pertencer a uma comunidade mais ampla com crenças comuns. A Religião pode proporcionar organização social e orientação moral, reforçando a estabilidade social como, também, a segurança. E como? Pelos rituais movidos de etapas importantes da vida como a fé, o nascimento, o casamento e a morte.

Cada Religião possui íntimo comportamento: um sikh reza com as mãos em frente ao rosto para obter contato direto com certa divindade, satisfazendo uma das principais necessidades da vida de uma pessoa religiosa. Os judeus oram em pé, orientando as mãos em direção ao Muro das Lamentações e os católicos, de joelhos, ao santo(a) preferido em lares e igrejas. 
Os budistas visitam o Nepal na busca dos lugares sagrados durante a vida de Sidarta, Buda. Um destes lugares, Lumbini, aonde Buda nasceu e ensinou sua filosofia aos peregrinos há milênios (600 a.C.). Os muçulmanos se dirigem à Meca, onde Muhammad viveu e os católicos, na busca ao passado, vão à Jerusalém.

Há séculos vimos estudando religiões, por meio de debates, em consonância às ideias dos profetas e líderes religiosos, além de se registrar as suas interpretações. À princípio, eruditos tinham interesse nas crenças e práticas de sua própria tradição religiosa; estilo esse que veio a ser conhecido como Teologia. Em seguida, começaram a comparar todas as religiões conhecidas no mundo terrestre, observando diferenças e o que havia de comum. Atualmente, um contingente de especialistas estuda as religiões como Philip Welkinson que se formou em Corpus Christi College, em Oxford, Inglaterra, um Autor preferido dos que têm vocação em estudos de cunho religioso.

Trata-se de encadeamento; sociólogos pesquisam o papel da sociedade no mundo atual, antropólogos estudam práticas, rituais e comportamentos religiosos, por meio de pesquisas como a datação carbônica; historiadores estudam e analisam a influência das religiões. Sobre acontecimentos, os fenomenologistas procuram, por sua vez, compreender os símbolos, doutrinas e rituais manifestados por meio delas. Mais do que nunca, os meios de comunicação e o crescimento de sociedades multiculturais oferecem uma compreensão maior sobre o fascínio das religiões do mundo vindo, assim, a influenciar o ensino da Religião nas Escolas. Enquanto no passado as crianças aprendiam apenas elementos de sua fé, atualmente é mais provável que se explique a elas a variedade de religiões.

O pensador e político alemão Karl Marx, do século XIX, considerava a Religião uma forma de disfarçar as causas da miséria humana:

Religião é o suspiro da criatura oprimida, o coração de um mundo sem coração, o Espírito de condições não-espirituais. É o ópio do povo.

As diversas religiões do mundo se apresentam em comum com características fundamentais e todas visam um objetivo que é o espiritual, seja pela união com um deus supremo ou deuses, seja pela busca de um estado mais elevado; exemplo, o empenho budista em atingir o nirvana.

Mas o assunto da pauta varia muito. Para a maioria das religiões, o conjunto de ideias e ensinamentos, intitulado Doutrina, em geral reflete noções básicas sobre a criação, o Universo, aborda Deus (ou deuses) e como se comportar como homem digno, a conduta humana. E nos mínimos detalhes: o hindu se alimenta com as mãos (a direita para pôr o alimento à boca); os ocidentais usam talheres! Quase sempre simplificada e exemplificada, por meio de mitos e narrativas, a Doutrina abrange questões essenciais de crença e prática, influenciando, assim, totalmente o comportamento, as leis e a Ética 
em geral, especificamente a Religiosa. Católicos, ortodoxos, muçulmanos, protestantes, mórmons, taoístas, confucionistas têm as mesmas condições: quem somos e para aonde vamos! Todavia, não há melhor presente que o tempo!

\section{O Catolicismo}

O Cristianismo é oriundo da Palestina; mas a renovação das almas dos homens daquela época remota surgiu com a fé hebraica, momento de período em que eram forçados à escravidão durante o Reinado do Faraó Ramsés III que, por sua vez, expulsou Moisés - criado e educado pelos egípcios -, dos muros do Palácio imperial, ao ser revelado o segredo de que sua origem era hebraica. Moisés, agora oficialmente cidadão hebreu, após caminhar em busca de novo destino pelo deserto e longe do militarismo e luxúrias egípcios, teve o privilégio, na História da Humanidade, de se comunicar, mediunicamente, com o Eterno, o qual o orientou a levar as suas origens, junto ao seu povo escravizado à terra prometida, Canaã (Kenáan).

O fato mediúnico entre Moisés e Deus encanta católicos e não-católicos: o dia em que Deus abriu caminhos do Mar da Galileia para a passagem e a salvação do seu Povo eleito, evitando a perseguição e a fúria do arrependimento do Faraó, o qual havia acordado e a posteriori arrependimento da saída dos hebreus do Egito.

O Mar Vermelho sofreu, em 1446 a.C., abertura no Estreito do Golfo Ácaba, fenômeno denominado "vento direcionado" aos moldes de uma pororoca, contado, inclusive, no Livro do Exodo. E nos mesmos moldes, Deus atende a Josué; desta vez, no Rio Jordão para que o Povo judeu atingisse Kenáan ao caminho da Terra Prometida após lutas sangrentas com o Exército de Jericó, além do enfrentamento com 31 outros Reinados.

Logo depois, Roma dominava quase todo o Oriente, quando surge $O$ Filho de Deus na Galileia, tendo a função de orientar o comportamento a ser seguido desde a época de Moisés, por meio da Lei mosaica, conhecida entre os católicos como Os Dez Mandamentos.

Depois da crucificação e da ascensão de Jesus, seus discípulos pregaram entre os judeus do Leste do Mediterrâneo e registraram sua fé em Escrituras, auxiliando, assim, a difundir o Cristianismo. Os esforços do missionário Paulo, falecido em 65 d.C. fizeram com que a Religião avançasse e a se consolidar em sólida base e meia segura no Império romano; assim como o próprio Império, o Cristianismo gerou duas correntes:

* a ocidental, baseada em Roma e

* a oriental, baseada em Constantinopla (hoje Istambul) 
Essas duas correntes originaram as modernas Igrejas católica e ortodoxa. Muito tempo depois, por meio do movimento conhecido como Reforma, emergiu o Protestantismo, terceira corrente do Cristianismo e as três correntes se tornaram dominantes na Religião cristã, conferindo-lhes grandes variedades e presença em todo o mundo.

A comunidade cristã primitiva era chamada de Corpo de Cristo, lembrando que os primeiros cristãos foram perseguidos pela sua fé e por isso praticavam o culto em segredo. A Igreja católica cresceu a partir da primitiva comunidade cristã de Roma que passou a considerar São Pedro o primeiro bispo da Cidade como, também, o primeiro Papa. Depois da queda de Roma, a Igreja sobreviveu na Europa Ocidental e se tornou a forma dominante do Cristianismo naquela região.

No século XXI, o Catolicismo é praticado em todo o mundo. Em premissa final:

Catolicismo é a Religião dos cristãos que reconhecem o Papa como autoridade máxima, que se confirma e expande por meio dos sacramentos, que venera a Virgem Maria e os santos, incluso Maria Madalena e que aceita todos os dogmas como verdades incontestáveis e fundamentais; tendo, por último, os atos litúrgicos mais importantes: a missa. Maria Madalena, nascida em Magdala, é citada por ser líder da Igreja primitiva e discípula de profunda conexão, além de seguidora em todos os momentos de Jesus.

Normalmente as missas são dominicais; todavia, as que homenageiam os santos e os mortos, têm datas de acordo com o calendário nacional: as últimas, são rezadas e/ou realizadas no sétimo dia após a morte do ente querido. Várias missas podem ser rezadas em igrejas diferentes para uma única pessoa; normalmente, homens e mulheres que honraram o seu país de origem. Como o líder da Igreja católica é o Papa, os católicos acreditam que ele é o sucessor direto de São Pedro sendo, portanto, o representante ou "Vigário" de Jesus Cristo na Terra.

Jesus Cristo deu a seu discípulo Simão o nome de Pedro, tradução de "rocha" e isso significava que ele deveria ser o fundamento da Igreja primitiva. Depois da ascensão de Jesus, São Pedro se tornou o líder dos cristãos, pregou em muitas partes do mundo e fundou a Igreja cristã romana. Antes de Pedro, Jesus viu em João Batista o homem catalisador para a mudança da Humanidade, no período em que por ele foi batizado.

Depois de anos de perseguição, a sorte dos cristãos mudou na Cidade eterna de Roma, no século IV d.C. O imperador Constantino I (307-337) se converteu ao Cristianismo, respaldado por sua mãe a imperatriz Helena e em 313 d.C. ordenou o fim 
das perseguições e o reconhecimento dos direitos civis aos cristãos em todo o Império romano. Em 324 d.C., o Cristianismo se tornou a Religião oficial do poderoso Império. ${ }^{3}$

Em 325 d.C., como Religião oficial do Império, cuja capital havia sido transferida para Constantinopla (Bizâncio) quando foi convocado o Concílio Ecumênico de Niceia. A legalização e a instituição do Cristianismo como Religião oficial do Império romano configuraram profunda mudança na História da Religião. Época em que o Império romano se afastou do seu passado, identificando-se mais com Israel, comungando a reverência pelas mesmas Escrituras sagradas, nas quais o Povo judeu baseava a sua existência. Tornou-se um Império bíblico, monoteísta e não muito diferente de Israel em suas crenças básicas, cujos súditos haviam sofrido semelhantes perseguições, algumas totalmente cruéis. E seu declínio acelerou-se.

Cumpre salientar que, a princípio, o Paganismo foi único e simplesmente tolerado; todavia, o Monoteísmo, ao se extinguir com a pluralidade de deuses, legitimou no Império romano o Absolutismo do monarca, cujo poder, soberano, não poderia ter limite jurídico; isto é, não poderia ser limitado pelos direitos públicos subjetivos ou, ainda, autolimitar-se, porque era a própria fonte do Direito. E os sucessores de Constantino começaram a se considerar divinos; o que, na verdade, já estava acontecendo desde Augusto, quando status super-humano foi concedido aos imperadores.

Por outro lado, de certo modo, já eram considerados divinos e não-só depois da morte. Os imperadores, na qualidade de imperator in regno suo, por direito que Deus diretamente lhes conferia, mestres das condições materiais e temporais da Igreja, ao mesmo tempo que buscavam reter a autoridade de Pontífice Máximo (Pontifex Maximus), ante a qual a autoridade civil se inclinava. E foi assim que o Império romano se tornou um Estado teocrático aos moldes do que já existia na Judeia, para o qual os delitos religiosos configuravam na qualificação de crimes políticos.

Segundo Karl Marx, o domínio da Religião passou a significar claramente a Religião do domínio no Império romano cristão (Herrschaft) e só se importava ao monarca que, por sua vez, personificava o Estado, cuja contextura institucional se assentava sob os dogmas da soberania una e indivisível da Coroa. A interpretação das leis dependia única e exclusivamente do soberano, observando-se que os intérpretes não podiam ser outros senão aos que ele designasse; desde que prestassem obediência.

Durante a Idade Média entendia-se na Europa que os povos deveriam se submeter aos preceitos da lex divina, estabelecidos nas revelações feitas pelo Deus Único

\footnotetext{
3 O Cristianismo pode ser considerado parte essencial da História do Império romano, dentro do qual a união e a disciplina permitiram que a Igreja crescesse e se formasse como Estado independente. De fato, o Cristianismo triunfou, merecidamente vitorioso, mas na versão de Paulo de Tarso, um Cristianismo nãopolítico, não-nacional, totalmente submisso e que pregava a obediência às autoridades e não em sua forma primitiva, escatológica, permeada pelo irredentismo judaico e pelas influências essênia e zelote.
} 
e das quais a Igreja católica era depositária. E aos preceitos da Lei Positiva que os homens formulavam, adaptando os princípios da lex naturalis à sua comunidade.

Premissa final: na verdade o Direito era consuetudinário, calcado aos usos e costumes da comunidade e, por sua vez, emanava o poder claramente do mais forte; tanto assim, que a palavra iustitia se alastrou, a ponto de designar o conjunto dos poderes senhoriais, conforme ensina Marc Bloch em A Sociedade Feudal, além de estar totalmente tutelado pela Igreja católica, lembrando que os clérigos também eram senhores feudais de armadura e espada, exercendo poderes temporais.

Enfatiza-se que os imperadores não eram chefes de Estado, tampouco os Reis; todavia, de princips que, por sua vez, lhes prestavam a hominum ou homagium, como vassalos; mas tinham direitos soberanos. Não havia autoridade da Lei e do Direito, exceto a vontade dos senhores feudais. E aos soberanos cabia a investidura dos bispos que, também por sua vez, deviam a hominum, além da execução de serviços feudais, vassalos, detentores de feudos seculares.

Ao longo da História da Religião e da História do Direito, com relação ao conceito de crime político, este sempre dependeu da análise conceitual do Estado em época determinada; assim, também, como fonte do Direito, enquanto ordenamento das relações sociais, além do nível de consciência possível que, por sua vez, reconhece a legitimidade da lei ou do costume de uma determinada comunidade.

Nos Estados teocráticos entre judeus que obedeciam à hagadá e halachá (Teologia e Lei do Judaísmo) ou os islâmicos que são regidos pelo Corão, as infrações religiosas se confundiam com os crimes políticos e eram punidas com a pena de morte. No Sacro Império romano-germânico, na Idade Média, as noções do Direito Divino (lex divina) e do Direito Natural (lex naturalis) se mesclaram, além de assentarem padrões normativos da Política em cenário de crônico conflito de jurisdição entre Papado e o Imperador; posteriormente, entre o Papado e as monarquias que estavam a emergir.

À medida que a Igreja católica e o regime feudal se entrelaçaram, o Direito se confundiu com a Teologia e a heresia configurou crime tanto eclesiástico quanto secular, publicum crimen. Era equiparado em equivalência ao crime de traição e também punível com a pena de morte, em consonância ao disposto no Liber I, sob o título De Haereticis, do Código de Justiniano (482-565 d.C.). Justiniano era cristão e fora condecorado ao trono do Império romano do Oriente em 527 d.C. com o nome de Flavius Petrus Sabbatius Justinianus. Ele reproduziu no De Haereticis, do seu Codex, a mesma norma aplicada na Roma antiga contra os primeiros cristãos e decretou a pena de morte contra os adeptos do Maniqueísmo, seita fundada pelo persa Manus ou Manichios, sintetizando todos os 
sistemas religiosos como o Dualismo de Zoroastro, da Babilônia, a Ética budista e por vezes alguns elementos do Cristianismo. ${ }^{4}$

Com tudo isso, se pode compreender ou pensar que os cristãos fossem membros inatacáveis, computando o passar dos séculos, da sociedade da época e o auxílio iminente das autoridades em sempre apoiá-los. Todavia, as autoridades não estavam de maneira alguma satisfeitas com o comportamento cristão e muito menos pela aparência facial ou roupagem deles. Tanto assim, os cristãos foram expostos a notáveis ridículos pelas classes cultas, as quais escarneciam de suas doutrinas, especificamente da Doutrina da Ressurreição dos mortos nos fins dos tempos.

Exemplo, os platônicos que os atacaram de maneira grotesca e deselegante quanto às interpretações de suas crenças na imortalidade da alma. E para grande parte da sociedade, o Cristianismo era classificado como filosofia bárbara ou, ainda, uma imitação desconsiderada pela Filosofia real para mentes débeis. Na segunda metade do século II d.C., um filósofo platônico, Celso, escreveu um texto atacando o Cristianismo, classificando-o de maneira rude, cujo título A Doutrina Verdadeira traz no final um resultado em que o Autor procurou desacreditar a própria entidade divina, ou seja, Jesus Cristo. Uma extração do texto, Celso repetiu a lenda já conhecida dos pagãos e dos judeus de que a Mãe Maria fora raptada por um soldado romano chamado Panthera e de que Jesus fora fruto e produto desta aventura.

Mediante os ataques do filósofo platônico Celso fossem depreciativos, o Cristianismo, por outro lado, estava em gradativa ascensão tanto no meio do povo quanto aos poucos se tornando mais respeitado nas camadas mais cultas da sociedade rica. Justino Mártir e Clemente, ambos de Alexandria, situada ao Norte africano, (150-215 d.C.) escreveram vários textos de conteúdo mais intenso em defesa de suas crenças; eram cristãos intelectualizados. Esses pergaminhos dos autores africanos são encontrados na

\footnotetext{
4 Os persas vinham do Leste do Mar Cáspio e ali a principal Religião era o Zoroastrismo, fundada por volta de 1200 a.C. por Zoroastro, também conhecido como Zaratustra, uma personalidade misteriosa, mas muito importante na área pérsica (hoje Bagdá). Ninguém sabe ao certo onde ele viveu seus anos de vida, possivelmente na mesma época de Homero. Historiadores alegam que provavelmente ele viveu no atual Irã; outros, acreditam que ele tenha vivido no Afeganistão. O fato é que Zaratustra pregou sua nova fé, geralmente identificada como uma Religião dualista que envolvia dois grandes deuses: um deus bom de luz e um deus do mal, da escuridão. O símbolo do deus bom é o fogo e Zoroastro conclamava seus seguidores a viver bem e entregar a sua sorte ao bom deus. Também acreditava que no futuro o bom deus triunfaria e recompensaria seus seguidores, ressuscitando-os dos mortos e os guiando para uma nova era de imortalidade e luz. Pode-se ver o Zoroastrismo como uma Religião monoteísta, assim como o Judaísmo e o Cristianismo, uma vez que o bom deus era considerado mais poderoso do que o mau deus. Com certeza, o Zoroastrismo parece ter tido uma das doutrinas associadas às religiões monoteístas como a vida após a morte, o julgamento e outros, antes do Cristianismo ou do Judaísmo e, modernamente, da Filosofia Espírita (a vida após a morte), fazendo de Zoroastro uma das mais influentes figuras que aqui viveu.
} 
Biblioteca Nacional de Alexandria; todavia, não-acessíveis sem permissão da diretoria do sistema de documentação africano.

No século III d.C., o Livro de Celso foi severamente rebatido por Orígenes Adamantino (185-254 d.C.), um personagem de considerável conceito e reputação intelectual, mesmo entre os filósofos pagãos. ${ }^{5}$

\section{A Nova Roma}

De forma lenta, os séculos II e III viram o Cristianismo crescer; todavia, de maneira contínua, apesar dos maiores esforços de muitos imperadores para impedi-lo, pois se tratava de uma preferência de crença para a minoria: não mais do que um entre dez romanos era cristão, no final desse período. Ainda não havia uma posição oficial sobre em que deveriam acreditar, cujo panorama iniciou a se mudar durante o período do século IV; possivelmente os 100 anos mais extraordinários que a Igreja católica jamais experimentou e a partir daí o Cristianismo se transformaria eternamente.

Neste fantástico período, com a conversão de Constantino (272-337 d.C.), um poderoso general que havia sido proclamado por suas tropas e que abraçou o Cristianismo. O cenário em momento crucial anterior à Batalha da Ponte Mílvia, 312 d.C., próximo à Roma, quando se preparava a enfrentar o seu inimigo e rival Licínio ao trono imperial. Mais tarde contou pessoalmente a Eusébio de Cesareia que naquele cenário ele próprio se perguntou sobre quais dos deuses poderia invocar em seu auxílio durante a batalha que se aproximava. Naquele momento surgiu aos céus o símbolo da cruz, envolta

5 O filósofo, teólogo e exegeta bíblico egípcio Orígenes foi o mais influente de todos os teólogos cristãos de língua grega e o arquiteto da maioria da subestrutura do dogma cristão e teologia bíblica, no final do período primitivo. Aos 17 anos de idade, 202 d.C., houve uma violenta perseguição em Alexandria, sendo seu pai neste período executado; para livrar a sua família da ruína, o jovem Orígenes aceitou a indicação em ser modesto catequista de uma Igreja local; nesse tempo acompanhou cursos avançados de Filosofia de muitos líderes espirituais de sua época, dando margem a posteriori em desenvolver a sua própria Escola, vivendo a partir daí uma vida ascética como um sábio filósofo. Algum tempo depois, o boato ocorrido de que dada a sua vida o motivo que o levou a se decidir em se castrar, história essa revelada um ano após a sua morte narrada pelo bispo de Cesareia, chamado Eusébio. Mas o enredo da história não deu credulidade aos que com ele viviam, uma vez o próprio Orígenes chamar aqueles que interpretavam literalmente o texto evangélico sobre castração, em Mateus 19:12, de "um pouco melhores que os idiotas". A estrelaguia de Orígenes em sua vida intelectual era a crença em que os melhores propósitos da Filosofia eram conciliáveis com os misteriosos projetos da sabedoria divina (o Logos) e que a dádiva da revelação e a busca humana da iluminação seriam encontradas nas Escrituras Sagradas. Dadas as viagens e influências é considerado o primeiro filósofo internacionalmente conhecido, do qual o Movimento cristão poderia se vangloriar. Escreveu "Sobre os Princípios" que ambiciosamente definiu como uma súmula introdutória de fé cristã com ampla abrangência, mostrando como a visão mundana concebe a Cosmologia, a Filosofia e a Religião. Em Cesareia, completou a sua maior obra: "Comentário sobre o Evangelho de João" e o seu texto mais influente: "Comentário sobre o Cânticos dos Cânticos". Orígenes foi perseguido em 249 d.C., torturado, preso e posto no colar de ferro, esticado em quatro espaços. Veio a falecer aos 69 anos de idade com a dignidade de mártir; todavia, sua espiritualidade e influência jamais serão apagadas. 
às nuvens esbranquecidas, fazendo-o a acatar o aviso celestial e marchou sob o signo da cruz, conforme havia sonhado um dia anterior, obtendo retumbante vitória para vir a ser o primeiro imperador romano cristão. ${ }^{6}$

A Nova Roma foi forte símbolo do novo Império, cujo centro de gravidade estava se transferindo em direção ao Leste europeu e à metade dominada de idioma grego do Mediterrâneo que fora construída sob a adoração ao Deus cristão e não às deidades gregas.

A Nova Roma foi mais conhecida como Constantinopla e, ao fim do século IV d.C., não era somente a Capital imperial; mas, a maior e culturalmente mais vibrante Cidade do Império romano oriental, tornando-a a ser classificada e catalogada na História da Humanidade como a mais importante Cidade do mundo cristão por mais de 1 mil anos! E nessa época, a Igreja e o Estado estavam se entrelaçando intimamente, porque a Igreja desfrutava da proteção e do apadrinhamento dos imperadores.

Todavia, em troca, deveria se conduzir em consonância com as ordens jurídicas e sociais da autoridade estatal. Essa comunhão torna-se um problema ao Cristianismo que viria à tona de maneira inesquecível em outro grande evento do século IV d.C., marcando a Religião para sempre: a crise ariana.

\section{A crise ariana}

A paz é uma utopia; todavia, entende-se assim do porquê ela não exista: a necessidade de uma linha contínua no intuito de que grandes ou regulares Nações não intervenham umas às outras, incluso instituições políticas, jurídicas ou religiosas. E em 320 d.C., o bispo de Alexandria, Alexandre, realizou um Sínodo dos Bispos locais que,

6 Constantino era filho da imperatriz Helena como citado atrás. A imperatriz, aos 70 anos de idade, seguiu de Roma à Jerusalém na busca da cruz que serviu de punição ao Filho de Deus. Helena reformulou Jerusalém; quanto à cruz achava que havia encontrado: foi desmontada em pedaços que serviram de relíquias pelo mundo todo. Constantino fora um dos maiores imperadores da História de Roma: reaparelhou o Exército romano, revitalizou a economia e conseguiu com que o Império - à beira da falência pela associação de falsificação de moedas, corrupção, instabilidade política e ameaças externas - sobrevivesse. Embora mais se preocupasse com a unidade religiosa do que com a precisão doutrinal. Havia sido batizado, embora já velho, usos e costumes daquela época, principalmente entre os militares. Dentre suas reformas, o domingo fora transformado em dia santo, em parâmetro às leis mosaicas, que considera o sábado o dia do descanso. Todavia, o mais impressionante dos seus atos foi o de que o imperador fundasse nova capital imperial ao Leste europeu conhecida como a Nova Roma e construída no lugar de uma antiga cidade chamada Bizâncio, localizada na costa ocidental do Bósforo, canal que liga o Mar Negro ao Mediterrâneo. Na conversão de Constantino, ele contou que por volta do meio-dia, quando o dia começava a declinar, tinha visto com seus próprios olhos o lábaro de uma cruz resplandecente nos Céus, abaixo do Sol, ostentando a inscrição "VENCER POR ISTO". A esse sinal, ele foi tomado de surpresa assim como o seu próprio Exército que o acompanhava na missão e testemunhou junto aos seus homens militares o milagre. Essa narrativa histórica foi extraída de "A Vida de Constantino", escrita por Eusébio de Cesareia, escritor e historiador cristão, que viveu na primeira metade do século IV d.C. 
por sua vez, condenou o pensamento de Ário (250-336 d.C.), ${ }^{7}$ um presbiteriano popular da Igreja de Alexandria.

Ele havia escrito várias circulares expondo suas ações, ou seja, opiniões na relação entre Deus e Jesus Cristo. Mediante o ato, fora severamente condenado, lembrando que naquela época, século II, teólogos, cristãos - exemplo Justino Mártir -, se utilizaram da velha ideia do Logos, basicamente endossada pela filosofia pagã, no sentido de expressar essa relação.

Jesus Cristo era o Logos, espécie de semideus que agia como o representante de Deus e isso constituiu a base para o desenvolvimento do que viria a ser a Doutrina da Trindade sustentada por Orígenes; base de aproximação entre Pai, Filho e Espírito Santo. Ário, teólogo conservador, recorreu da sua condenação e em seu exílio na Palestina escreveu sucessivas e sugestivas cartas, expressando as suas ideias, as quais se tornaram notavelmente populares, quando o imperador Constantino convocou todos os bispos para discutir o assunto.

O cenário: Niceia, o primeiro Concílio Ecumênico, do outro lado do Bósforo (hoje Turquia), a partir de Constantinopla, em 325 d.C. Os bispos junto ao imperador acordaram que a condenação de Ário era razoável como, também, entraram em acordo sobre uma nova declaração de fé à luz da questão. ${ }^{8}$

7 Ário era um sacerdote de Alexandria e afirmava a existência de um Deus Único eterno, onipotente, indivisível, imutável, que não podia comunicar seu Ser por geração. Logo, Ário negava que o Eterno houvesse gerado o seu Filho desde sempre. O Cristo, Filho de Deus é Deus de Deus, Luz de Luz, Deus verdadeiro de Deus verdadeiro. Ário falou no Verbo como se tivesse sido criado antes de todos os tempos, com a finalidade de ser apenas instrumento e executor na criação deste mundo. Em seu pensamento, o Verbo é a melhor das criaturas, mas não é igual a Deus nem eterno como Ele na Encarnação, quando Jesus nasceu, diz esse herege, que o Verbo se tornou sua alma. Ainda em referência a Jesus Cristo, declarava que foi apenas adotado por Deus e não é filho verdadeiro da sua mesma substância. Era difícil para Ário pensar que, vindo a este mundo, se o Cristo fosse o verdadeiro Deus, pudesse sofrer fome, sede, frio ou cansaço. Se Jesus Cristo fosse igual a Deus, não poderia mudar, porque Deus é imutável; não poderia tornar a carne corruptível, porque Deus é incorruptível. Atanásio, bispo da Igreja de Alexandria, foi quem comandou a luta contra Ário, expulso cinco vezes da sede episcopal pelos próprios seguidores de Ário. No exílio, Atanásio esteve na Gália e em Roma e foi muitas vezes acolhido pelos monges no deserto do Egito. Sua obra apologética mais importante foi sem dúvida "Orationes contra Arianos", na qual defende a doutrina proclamada pelo Concílio e declarou que "Deus gera seu Filho eternamente e este Único Filho é consubstancial ao Pai. Jesus Cristo é Deus próximo e humilde”. São Paulo, em suas palavras sábias como apóstolo, comenta que o Filho de Deus "não se apegou à sua divindade, mas esvaziou-se dela". Isto é o que se chama 'kénosis' e o apóstolo diz que "Ele assumiu a condição humana até a morte, e morte na cruz, tendo alcançado a ressurreição e a glória que nunca deixou de ser sua".

8 ... à luz da questão: "Nós cremos em Deus, o Pai Todo-Poderoso, Criador de todas as coisas, visíveis e invisíveis, em único Senhor, Jesus Cristo, filho unigênito do Pai, feito da essência do Pai, Deus de Deus, luz de luz, Deus verdadeiro, gerado, não criado, consubstancial ao Pai e por quem tudo foi criado, no Céu e na Terra, e que virá julgar os vivos e os mortos. E no Espírito Santo". Este "símbolo" de Niceia viria a se tornar o mais importante texto cristão produzido, base do "Credo de Niceno" que ainda hoje, século XXI, é recitado nas Igrejas católicas. 
O símbolo de Niceia como visto viria a se tornar o mais importante texto cristão jamais produzido e base do Credo de Niceno que ainda até hoje é recitado na Igreja católica e inserido com veemência no âmbito do Direito Canônico. O Credo é similar em sua conduta a outro texto: o Credo dos Apóstolos, além de ser constituído na mesma época. Enfim, movimento surgido em algum momento da História do Cristianismo, no intuito de que alguns teóricos conspiradores tentassem provar que o Cristianismo, como hoje o conhecemos, fora uma invenção do imperador Constantino.

Historiadores relatam que naquela época os bispos estavam seriamente divididos sobre a questão jurídico-religiosa de Ário e que a facção pró-Ário fora silenciada à força por ordens do imperador e que o próprio teólogo fora derrotado, além de que, nesse Concílio, Constantino decretou quais os livros que fariam parte da integração da Bíblia, efetivamente reescrevendo assim a História da Igreja primitiva. O Concílio considerou, também, muitos outros e diversos assuntos, incluso alguns relativos à organização da Igreja e a data da Páscoa, mas não à questão do Cânon da Escritura, estabelecida meio século mais tarde.

Após a morte de Constantino, uma confusão: seus filhos tinham o nome de Constantino II, Constante e Constâncio. Não é que causou confusão pelos nomes! O imperador havia dividido o Império entre eles: Constantino II herdou a região do Ocidente; Constante a do meio e Constâncio a Oriental. Todos os três receberam educação cristã. Constantino II entrou em guerra contra seu irmão Constante e nela foi morto. O seu território fora incorporado ao de Constante, significando enorme desenvolvimento, pois o território de Constante era o do idioma latino, a metade ocidental do Império, ao passo que o de Constâncio era o de idioma grego, a metade oriental, embora oficialmente o Império romano fosse o único domínio, essa duplicidade de comando culminou com a sua divisão em duas civilizações completamente distintas.

Por fim, a história do século IV d.C. é contemplada com a conversão de Constantino, constituindo os grandes eventos da época do Cristianismo inicial; dentre eles, o da comemoração da Páscoa (Pêssach). Embora se espalhando desde o século III d.C., o século IV - cenário das controvérsias arianas -, advém o Catolicismo e seus dogmas movido a várias jornadas de períodos como a do Movimento Monástico ${ }^{9}$ e a do Jovianismo.

O Movimento Monástico continuou a possuir extrema importância no Cristianismo durante muitos séculos e ainda, por incrível, permanece importante em muitas Igrejas da atualidade, mas também como fonte de conflitos, porque os mosteiros tornar-se-iam grandes e poderosos e seus líderes os "abades" - vocábulo inspirado na palavra "pai" usada pelos monges do deserto - eram, em muitos casos, figuras extremamente importantes. Assim, havia conflito potencial entre o sistema monástico e os bispos. Entretanto, o próprio sistema monástico era controverso. E em que medida os cristãos seriam chamados a viver como esses monges? A questão foi fonte de novas disputas, naquela época! 
Joviano viveu em Roma no século IV. Era monge, mas interrompeu seu estilo de vida e se tornou eloquente crítico das práticas ascéticas; atacava especialmente aqueles que acreditavam que uma vida virginal fosse melhor que a de casado. Dizia que não era melhor jejuar do que se alimentar e que no Céu todos eram recompensados da mesma maneira. A tese de Joviano não foi concordada pelo escritor, diretor espiritual Jerônimo, homem erudito sempre mal humorado; todavia, uma personalidade no seu tempo. Jerônimo, ao contrário, exaltava o estado virginal e ensinava que o sexo era um mal. Enfatizava a virgindade de Maria, Mãe de Jesus Cristo. Essa controvérsia, assistida até hoje no século XXI (crença dos monges, por exemplo), veio a afetar o século IV e o início do século $\mathrm{V}$.

Esse é o período de Santo Aurélio Agostinho que significa pequeno imperador. Quem não conheceu sua vida assumida por disciplina rigorosa e autonegação! Em 410 d.C., ocorreu um evento que repercutiu em todo o universo do Mediterrâneo: a cidade de Roma fora invadida e saqueada por Alarico, eleito Rei Visigodo, e suas hostes bárbaras.

Até então, Roma nunca havia sido atacada desta maneira e o efeito psicológico nela produzido não foi diferente do sofrido pelos EUA, após ataques terroristas de 11 de setembro de 2001, episódios da tautologia histórica!

Da Pérsia à China, o Catolicismo foi em linha crescente assustadora, contribuindo aos direitos comunitários, consuetudinários e penais, conquistas das mais diversas, inclusive entre os mongóis e a Dinastia Yuan.

Em 781 d.C., para o acervo da documentação universal dirigida à História da Humanidade, do Direito e da Religião, período em que uma estela ou monumento de pedra, elaborada em Changam, e redescoberta em 1625, mostra a existência de antiga Igreja chinesa que tinha sido completamente esquecida. No seu interior, grande número de estelas lavradas para as igrejas das capitais de Províncias, onde muitos sacerdotes e bispos tiveram seus nomes inscritos e todos aparentemente estrangeiros.

O mais notável é a de que essas estelas, constatado em 1907, apresentavam se tratar de documentos religiosos de uma caverna perto de Dunhuang, a maioria budista confucionista e taoista; alguns poucos, denominados de "Sutras de Jesus" que nada mais são do que pergaminhos escritos por membros daquela antiga Igreja. Por fim, a parte mais extraordinária é a de que um desses escritos foi identificado como datado no ano de 641 d.C.: um dos primeiros documentos religiosos a utilizar o sistema "d.C." para datação. Os escritos continham reconhecidamente doutrinas cristãs, reproduzindo razoáveis e imprecisas traduções do conteúdo dos Evangelhos, especialmente os ensinamentos de “Ye Su”: Jesus! 
7. O Papado

A ascensão papal à proeminência inicia-se na época do Império romano, uma vez Roma ter sido importante para os cristãos; não-somente como a primeira Cidade do Império, mas também o local onde Pedro e Paulo foram martirizados. Só estando em Roma é que se possa compreender Roma.

Em Constantinopla, um veneziano fora empossado como o novo patriarca latino da Cidade; época em que havia tentativa no intuito de pôr a Igreja bizantina sob o jugo papal. E um cardeal de nome Pelágio se fez excepcionalmente impopular, perseguindo todos aqueles que não aceitassem a supremacia do Papa ou, ainda, em se utilizar ritos latinos, da região do Lácio, nos serviços eclesiásticos. Os ocidentais não puderam defender Constantinopla, porque possuíam recursos totalmente limitados, mesmo período quando os búlgaros aproveitaram a oportunidade para desferir novos ataques à Cidade.

Enfim, a Igreja primitiva se baseava na grande fé, o que não se distancia da Igreja moderna católica de hoje, além do que sua Religião havia sido transmitida de Jesus Cristo para os seus apóstolos. Por isso, as igrejas que na realidade tinham sido fundadas pelos apóstolos eram consideradas como normativas e nos debates as decisões de seus bispos eram especialmente significativas, porque representavam a fundação apostólica.

O Concílio de Calcedônia decretou que havia cinco dioceses em consonância com a autoridade papal, chamadas Sés dos Patriarcas: Roma, Jerusalém, Alexandria, Antioquia e Constantinopla. Todavia, do ponto de vista teológico, Roma sempre foi a Cidade Eterna e se tornava cada vez mais importante ao Ocidente, mesmo porque a transformação da Sé romana tinha raízes no século IV d.C. Um dos bispos mais influentes foi Dâmaso I que possuía elevada visão de sua própria autoridade. Ele se referia à Roma como a Sé Apostólica e a si mesmo como pontifex maximus. Dâmaso I defendia que a autoridade do bispo em Roma havia sido estabelecida pelo próprio Jesus Cristo, lembrando que ele se referenciava em Mateus 16: 18-19, quando Jesus disse a Pedro:

Tu és Pedro, e sobre esta pedra edificarei a minha Igreja, as portas do inferno não prevalecerão contra ela. Eu te darei as chaves do Reino dos Céus: tudo o que ligares na terra será ligado nos Céus e, tudo o que desligares na terra, será desligado nos Céus.

O nome "Pedro" vem da palavra grega que significa "rocha" como vimos; assim, nesta passagem, Jesus deu a Pedro, que tinha originalmente o nome de Simão, uma espécie de apelido. E por esse motivo Dâmaso I foi o primeiro a sustentar que ao conceder autoridade a Pedro, Jesus tivera a intenção de passar o título aos seus sucessores. E as ideias de Dâmaso I foram prevalecidas, a ponto de passar ao seu sucessor Sirício este título, sendo ele o primeiro a usá-lo, isto é, o título de Papa, que significa Pai. 
Em 497 d.C., um Sínodo em Roma, o primeiro que se tem notícia de que ali se aclamou oficialmente o Papa, à época de Gelásio I como o "Vigário de Cristo”. E os fundamentos teológicos do Poder do Papado estavam lançados; nos anos seguintes, funções políticas também foram criadas.

Como vários Reis bárbaros vinham e partiam tanto na Itália quanto em outras regiões do Ocidente, o Papado era a única instituição política estável e essa circunstância levou Gregório, o Grande, a se tornar o Papa em 590 d.C., assumindo juridicamente todas as finanças em Roma, assim como o abastecimento de alimentos e água, além do policiamento, usando os monges (antes ele também era monge) como guardas-civis.

Gregório fora um Papa honesto, diplomata perfeito e incorruptível no século IV d.C., ensinando que os sete capitais não são oriundos da Bíblia e nem nela estão assinalados: viriam, por sua vez, da Ética da Religião. Acreditava, como o Papa Francisco atual, que sua principal missão era a de socorrer os pobres e, para que atingisse esse objetivo, reorganizou as finanças da Igreja, tornando-a assustadoramente eficiente e poderosa.

$\mathrm{Na}$ época do Papa Zacarias (741-752), o Papado chegou a possuir consideráveis áreas de terras compradas e doadas na Itália. Por intermédio desse Papa, chegou-se a cunhar as suas próprias moedas. Ele participou da diplomacia internacional como observador desinteressado e exímio árbitro; todavia, como um Rei entre os Reis, além de ter sido também governador do que agora era chamado de "a República de São Pedro" que, no futuro, veio a ser o Estado do Vaticano.

O Papado medieval se preocupou muito com as missões, dando origem futura, por intermédio de Santo Inácio de Loyola, às missões das Américas. Era a Companhia de Jesus, conhecida como Os Jesuitas ou a Ordem Missionária Jesuitica das Américas e das Índias.

Houve papas como os Bórgia que pouco participaram para a estabilidade da Igreja: corrupção, assassinatos e ganância contribuíram em cenário peculiar dessas gestões. As conquistas da Família Bórgia desde o Papa Alexandre VI - que envenenou todos os seus cardeais - foram imensas, usurpando grande parte dos Estados-papais como Rimini, Ravena, Romania, Modena, Sena, Bologna, Ferrara, Faenza e outros demais.

À época, a Igreja não tinha comportamento exemplar. O Papado tinha caído em espantoso descrédito; no século IX d.C. poderosos papas da Idade Média se tornaram papas insignificantes, nada mais do que fantoches do Governo estrangeiro. Até uma mulher havia conseguido se tornar Papa sem que ninguém notasse: o mito da "Papisa Joana", tornando-se uma lenda pitoresca e burlesca!

A situação melhorou por meio de Leão IX, após período dos mais corruptos. Mais adiante, Bento IX - libertino que se tornou Papa com apenas 12 anos de idade, além de ter renunciado, na busca da venda do Papado a favor de seu padrinho a quem depôs 
logo em seguida -, torna-se mais um episódio lamentável na história do Papado. Dos mais significativos foram dois: Leão IX que chegou ao Papado em 1049 e Gregório VII (10731085) que até hoje é reverenciado como santo.

A Igreja católica à medida que vinha se desenvolvendo na busca de nova autocompreensão ou nova força de fé tem seguido esse trajeto desde a incansável luta contra o Protestantismo.

Com mais de 3,6 bilhões de católicos que, após a gestão dos Papas João Paulo II, Bento XVI e do atual Francisco, tem alcançado o intento religioso, principalmente devido ao carisma deste último - Papa Jorge Mario Bergoglio, nascido na Argentina -, que conquistou o mundo inteiro como Brasil, EUA, Estados europeus e africanos. O Papa atual fala a língua do Povo, se refere aos direitos do Homem, se embasa pelos conhecimentos que possui dos Direitos Humanos, do Direito Consuetudinário, Direito Penal e Direito Civil.

A cartilha católica, considerada caquética pelos católicos, tem se modernizado auxiliada pela influência do atual Papa que tenta se alinhar ao mundo moderno; como é o caso do Direito Civil nas áreas Família/Matrimônio, uma vez o País, embora laico, conseguir aprovação, no âmbito do Supremo Tribunal Federal, da união entre duas pessoas do mesmo sexo em 2014; aos divorciados a contrair novo casamento em cerimônia religiosa cristã; anseios reivindicados pelo Povo brasileiro.

$\mathrm{O}$ atual Papa respeita novos comportamentos da moderna sociedade, mas não aprova - em consonância às regras do Vaticano - a união homoafetiva. A pauta vem sendo analisada por comissões do Vaticano; daí se incluir a Igreja católica como reformista, neste século XXI.

A nova sociedade parental tem sido aceita em quase todos os países do primeiro mundo. No ano de 2015, mais de 8 mil casamentos homoafetivos foram realizados nos cartórios cíveis brasileiros. Em parâmetro, a maior surpresa foram empecilhos sociais vindos da sociedade francesa, aonde o lema maior da soberania daquele país ser o da Igualdade, Liberdade e Fraternidade.

O Papa Jorge Mario Bergoglio lançou, em 2016, nos salões do Vaticano seu primeiro livro intitulado O Nome de Deus é Misericórdia, no qual explora o tema em si e tem nele uma postura acolhedora aos que pecam. Neste mesmo ano, em Havana, o Papa Francisco se encontrou pela primeira vez depois de 1.000 anos (século XI) com o patriarca da Igreja ortodoxa na mostra de pretensa conciliação de paz. Os religiosos estão preocupados com a perseguição aos cristãos.

Em 8 de dezembro de 2015, no Rio de Janeiro, o Papa protagonizou o Jubileu Extraordinário da Misericórdia, cerimônia realizada em anos santos, período em que padres pedem melhorias à saúde entre as mulheres que praticam aborto e segurança 
às agredidas, lembrando que toda vez que uma mulher é agredida é a sociedade que assim o é; e o perdão aos católicos que praticaram erros.

O término foi beneficente aos católicos, cujo resultado é o de que doravante bispos têm permissão de anular casamentos, uma reforma que levou 100 anos para acontecer. Na época, em retorno à Itália, o Papa foi indagado pelos repórteres internacionais sobre a comunhão entre os gays; ao responder, mostra a sua humildade com a famosa frase "Quem sou Eu para julgá-los?”

O Papa Francisco, intermediário na aproximação de Cuba/EUA, se posicionou como um dos maiores líderes do mundo; neste ano, visitou as Filipinas e países do Continente africano. A sua franqueza provoca polêmicas quando aborda os temas luxúria e gastos exagerados e no Congresso norte-americano, ano passado, alegou a receptividade que se deva ter com relação aos refugiados vindos do Norte-africano, Síria, Líbano à procura de uma vida melhor com a frase marcante: "muitos de nós fomos estrangeiros um dia”. Ele trabalha com minúcias para que as regras religiosas nunca devam estar acima das Leis de qualquer país católico.

Ressalta-se a Encíclica deste ano, escrita de próprio punho, em 192 páginas, demonstrando a preocupação do Papa Francisco com o desenvolvimento sustentável; nela, impulsiona para uma solução direcional e imediata à proteção do meio ambiente em todo o planeta.

O Papa Francisco reconhece o genocídio de mais de 2 mil armênios causado pelo Império turco-otomano, em 1915, marcando com tristeza a História da Humanidade. Em junho, visitou o Memorial Armênio, ocasião em que lamentou o episódio no qual armênios foram mortos pelos turcos-otomanos que, por sua vez, censuravam a aproximação da Armênia com a Rússia durante a I Guerra Mundial e pede conciliação entre a Igreja Apostólica Armênia e a Igreja Católica Romana.

Embora haja separação Estado/Igreja há séculos, a instituição religiosa nunca deixou de intervir - direta ou indiretamente -, operando nas doutrinas legislativas, principalmente nos Estados católicos, lembrando que o seu antecessor, Bento XVI, desde a época de seu aniversário em festa oferecida pelo presidente George Bush, na Casa Branca, se encontrou em situação embaraçosa sobre a pauta "padres pedófilos", praticamente sanado na atual gestão papal, por meio de severa punição.

As maiores reformas vêm por intermédio do Corpus Juris Canonici que continha as primeiras leis de quase dois séculos, as quais foram elaboradas pela Suprema Autoridade dos Romanos Pontifices, auxiliado pelo Decreto de Graciano, o qual, por sua vez, continha as leis anteriores e que consta do Liber Extra, de Gregório IX, do Liber VI, de Bonifácio VIII, das Clementinas (coleção de Clemente V).

As leis foram promulgadas pelo Papa João XXII. As posteriores, à época da Reforma católica dadas pelo Concílio de Trento, foram promulgadas mais tarde 
por diversos Dicastérios da Cúria romana e nunca foram reunidas. Elas se encontram documentadas em cofres do Instituto de Obras Religiosas (IOR) do Banco do Vaticano.

O lugar mais sagrado do Vaticano é o do enquadramento da Capela Clementina - abaixo da Cúpula de Michelangelo - onde se encontram os túmulos do Papa Pio XII e de Pedro, o primeiro Papa da História do Catolicismo.

No Concílio do Vaticano I, bispos solicitaram que houvesse uma coletânea de leis, tarefa iniciada pelo Papa Pio X e sucedida pelo Papa Bento XV, que a terminou depois de vinte anos, entrando em vigor em 1918.

Nova reunião, em 25 de janeiro de 1959, a pedido do Papa João XXIII realizada por uma Comissão composta de vários membros e constituída devidamente em 28 de março de 1963. O Papa Paulo VI a concluiu e o novo Código Canônico com 1.752 cânones foi publicado na Eterna Roma, Residência do Vaticano, em 25 de janeiro de 1983.

O Direito Canônico é assim definido, em consonância com os ensinamentos do Professor Rafael Llano Cifuentes, de Salamanca, Espanha:

[...] define-se o Direito Canônico como o conjunto de normas jurídicas, de origem divina ou humana, reconhecidas ou promulgadas pela autoridade competente da Igreja católica, que determinam a organização e a atuação da própria Igreja e de seus fiéis, em relação aos fins que lhes são próprios.

O Papa Paulo VI em Alocução, de 17 de agosto de 1966, se pronuncia:

[...] sabemos muito bem que, em muitos lugares, se vê com antipatia a atividade legisladora da Igreja como se fosse contrária à liberdade dos filhos de Deus, antiética do Espírito do Evangelho e como se estorvasse a espontânea expressão dos carismas próprios do Povo de Deus e detivesse o desenvolvimento histórico do organismo eclesiástico que fica proscrito e atrasado em relação ao desenvolvimento histórico da sociedade temporal. Mas não vemos como a Igreja católica, se quer permanecer fiel, ser consequente com os princípios construtivos dados por seu Divino Fundador, pode prescindir de dar-se a si mesmo um Direito Canônico: se a Igreja é uma sociedade visível, hierárquica, comprometida em uma missão salvadora, que não admite senão uma unívoca e determinada realização, que deve ser conservada rigorosamente e defendida apostolicamente, responsável pela saúde dos próprios fiéis e da evangelização da Revelação e das necessidades que brotam continuamente da sua vida interior e exterior $[\ldots]$

As contribuições do Direito Canônico assim como as das origens do regime jurídico brasileiro, por meio do Direito Romano, têm história densa, complexa, longa e contínua. A interferência do Direito Canônico na composição do Direito Civil não encontra a sua razão de ser apenas na interação de influências jurídicas e sociais, uma vez o Direito 
Canônico possuir o perfil de matéria clássica que repercute com tradição em grande parte de currículos acadêmicos. A maioria das Academias de Direito do mundo, enfatizando as de origens latina e europeia, o emprega em grades de níveis universitários há séculos. Em conexão similar, o Direito Romano. A exemplo da cidade histórica de Toledo, na Espanha.

O importante é o embasamento da necessidade cada vez maior das realidades social, jurídica e religiosa em que o mundo atual vem passando, notadamente os da América Latina, a maioria países onde impera o Catolicismo. Embora um Estado laico, o nosso País tem a maioria de seus habitantes praticantes da Religião católica (63\%), seguida pelos protestantes (18\%), evangélicos (17\%) e $2 \%$ ateus.

Os pertencentes ao Espiritismo são considerados cristãos filósofos, uma vez classificados como estudiosos da doutrina da Filosofia Espírita. No País, encontram-se imensas camadas sociais de ortodoxos (no bairro do Paraíso em São Paulo a mais bela Igreja), judeus (belíssimas sinagogas e o Memorial da Imigração Judaica); muçulmanos (dentre as mesquitas, a mais antiga se localiza no bairro do Pary; a mais bela é a de Foz de Iguaçu). Mas até hoje ainda não contabilizados corretamente.

A Igreja católica é uma entidade religiosa; todavia, também entidade política e econômica, desde a época de Constantinopla e do Reinado da imperatriz Teodora que, de prostituta à tecelã, conquistou o amor do imperador Justiniano com quem se casou, tornando-se a mulher mais importante de sua época tanto no Poder quanto no meio político-religioso. Embora haja total tradição, lamenta-se - nos dias de hoje - a ausência de representantes femininas na conduta da moderna Igreja católica!

\section{O Direito brasileiro}

1. Introdução

Hobbes, no capítulo XV, do Leviathan sustentou que o Direito vem do Estado; para o filósofo, o Estado é uma unidade e sua soberania, absoluta. E o Princípio de Ulpiano reaparece também em Hobbes, segundo o qual princeps legibus solutus. As associações que são formadas no interior do Estado não passam mais do que vermes, nas entranhas do Leviathan. Isso nos faz lembrar o que Rousseau e Kant afirmaram: que só é lei a expressão da vontade do soberano. John Austin afirmou que o Direito é o Direito Positivo emanado pelo Estado e Stephan Leacock segue o caminho de Austin, afirmando que a soberania é a Lei gerada pelo Poder.

A Escola de Viena considerada a mais alta expressão do estatalismo fundiu em uma única a realidade Estado/Direito. E contra esse monismo, que só aponta como Direito o sistema legal posto pelo Estado, vieram os teóricos do pluralismo jurídico que, por sua vez, sustentam que ao lado do Direito do Estado ou sem o Direito do Estado e 
mesmo contra o Direito do Estado existem ordenações jurídicas múltiplas que jurídica e politicamente geraram a instituição Direito.

Em As Teorias da Idade Média, Gierke que se dedicou às teorias políticas da Idade Média chegou à conclusão de que toda comunidade orgânica e todo organismo social é capaz de produzir o Direito. O Estado não é a fonte única e exclusiva da norma jurídica, uma vez a vida jurídica e a vida do Estado não deixam de ser dois lados autônomos da vida social. Para Gierke, as coletividades têm uma capacidade de querer e de agir semelhante ou nos mesmos moldes às dos indivíduos humanos, porque o Direito não cria tal capacidade; todavia, lhe confere a qualidade de jurídica.

Esta tese pluralista se amplificou com Maurice Hauriou, Georges Renard até a do Direito Livre. O institucionalismo e suas ideias centrais vêm dos sindicalistas, para os quais a ordem social é o produto dos imperativos econômicos e em consequência as associações econômicas são as únicas de importância na organização social.

Os sindicatos são as unidades fundamentais do sistema; têm ampla autonomia para a sua regulamentação e interesses próprios à comunidade. E cada Federação de sindicatos compõe uma República profissional e as Repúblicas profissionais são coordenadas pelo Estado que, por sua vez, compõem a Federação econômica.

Os cidadãos e o funcionalismo público (federal, estadual e municipal) exercem o papel de instrumentos a serviço do Estado e o que importa não é o conjunto dos direitos do indivíduo, mas o conjunto dos seus deveres. Uma Nação funciona corretamente se o Estado assiste às áreas de Educação e a do Emprego Social; educar, dar condições à saúde e à moradia, sustentabilidade aos empregos, por meio da indústria e do comércio: preenchidos estes requisitos, há resultados benéficos às camadas sociais de uma comunidade e as Nações que têm esses registros só devem esperar pela prosperidade. Governos sérios e honestos.

2. O Direito, a Igreja e a época atual

2.1. Da Religião nasce o Direito e a Ética; a História da Religião é a história do homem na busca de quanto mais se organizarem, a vida será melhor, oriundo do conjunto de palavras de Francisco (Chico) Xavier: disciplina, disciplina e disciplina, eis o sucesso!

A Religião necessitava nas áreas eclesiais de aperfeiçoamento encontrado no Direito e o homem, na busca de produção, industrialização, relações internacionais procurou entendê-lo e aperfeiçoá-lo. Mas nada é possível sem a Ética. O nosso Direito se embasa no conceito de sociedade perfeita ou, pelo menos, na sua procura, que se traduz por sociedade soberana ou independente e no princípio jurídico ubi societas ibi ius. 
Em Nas Fontes do Direito, Hauriou assevera que o movimento lento e uniforme das ordens sociais é análogo ao movimento existente nos organismos vivos. E a Ciência já conseguiu provar que estes organismos se acham em perpétua transformação, sendo a Igreja católica moderna um exemplo, colaborando com o consenso das divindades de se casarem novamente; como, também, colaborando por meio do Direito Positivo que exige sempre três elementos essenciais: autonomia da vontade individual, autonomia do Poder Político e a autonomia da Ordem.

O Direito brasileiro é embasado no Direito Positivo, ${ }^{10}$ no Direito Romano e nos Direitos italiano, francês, alemão e inglês. O instituto do impeachment é oriundo da jurisdição inglesa. O Brasil é um Estado laico, embora $3 / 4$ de sua população seja católica. A Igreja católica é embasada, por sua vez, no Direito Canônico.

Tanto a Igreja quanto o Estado - deixando para trás a junção Estado/ Igreja com o passar dos anos -, fizeram progressões ao auxílio da sociedade que, por sua vez, exigia o exercício de cidadania, além das funções estatais que são exercidas pelas instituições jurídicas e as corporações. A Igreja católica sempre respaldou os Estados católicos e até hoje tem junto ao Estado brasileiro influência eficaz, notadamente em áreas no âmbito do Direito Civil, Social e principalmente dos Direitos Humanos.

O Brasil foi colonizado pelos portugueses, capitaneados por Pedro Álvares Cabral em $1500^{11}$ e nos primeiros anos de sua civilização, missionários assistiram, em

10 A diferenciação entre as áreas da moralidade e o da juridicidade decorre de preocupação excessiva com a autonomia da Ciência Jurídica. Hans Kelsen nos ensina de que se está diante de um Direito Positivo, devese dizer que este pode ser um Direito moral ou imoral. E é lógico que se prefere o Direito moral ao imoral; porém, há de se reconhecer que ambos são vinculativos da conduta. Em síntese, um Direito Positivo pode contrariar algum mandamento de Justiça e nem por isso deixa de ser válido. Por isso o Direito Positivo é o Direito posto, de "positum" (posto e positivo) pela autoridade do legislador, dotado de validade, por obedecer a condições formais para tanto, pertencente a um determinado sistema jurídico. O Direito não precisa respeitar um mínimo moral para ser definido e aceito, uma vez a natureza do Direito, para ser garantida em sua construção, não requer nada além do valor jurídico. E aqui o Direito e Moral se separam. A exigência de uma separação entre Direito e Moral, Direito e Justiça, significa que a validade de uma ordem jurídica positiva é independente desta Moral Absoluta, única e válida, da Moral por excelência, de "A Moral", em consonância com Kelsen em "Teoria Pura do Direito". Validade e justiça de uma norma jurídica são juízos de valor diversos; portanto, norma pode ser válida e justa; válida e injusta; inválida e justa; inválida e injusta. Kelsen quis expurgar no âmago da teoria jurídica a preocupação com o que é justo e o que é injusto, mesmo porque o valor justiça é relativo e não há concordância entre os teóricos e entre os povos e civilizações de qual o definitivo conceito de justiça. Discutir justiça para Kelsen é única e exclusivamente tarefa ou competência da Ética, Ciência que se ocupa em estudar não normas jurídicas mas, sim, normas morais e que se incumbe de analisar ou detectar o certo e o errado, o justo e o injusto, área também absorvida pelos ministros da mais alta Corte do País, o Supremo Tribunal Federal (STF).

11 A expansão do território brasileiro, mais semelhante a um continente, veio por meio do português João Ramalho, recebido pelo cacique Tibiriçá. Enturmado com a civilização indígena, Ramalho teve várias mulheres índias, as quais geraram filhos que deram origem aos denominados os "bandeirantes" que são grupos de homens luso-brasileiros, mamelucos e indígenas, os quais desbravaram, a partir de São Vicente até os quadrantes de Norte/Sul, as terras do Brasil, catequizando os donos das terras e fundando cidades, dentre elas São Paulo, 1554. O perfil do brasileiro foi traçado pelos "bandeirantes", homens a maioria 
nome de Igrejas católicas portuguesas e espanholas, não-só seus habitantes naturais, os índios, como os primeiros colonos que vieram aqui trabalhar e viver. $\mathrm{O}$ Estado brasileiro sempre foi influenciado pelas classes dominantes, por meio de favoritismos e pela falta de liderança.

Desde o descobrimento, a distribuição de terras não existia, um severo monopólio ditado por pequeno grupo, constituindo, assim, uma das maiores desigualdades desde os tempos coloniais, durante o Império e na República atual; ainda deixando muito a desejar. Embora haja a Fundação do Índio (Funai), os nativos até hoje encontram empecilhos e entraves em suas reivindicações, notadamente a demarcação geográfica territorial.

O Brasil é um País que luta pelas melhores condições de vida, onde se fala a mesma língua mesclada aos deliciosos sotaques regionais. As suas instituições têm pleno poder; todavia, uma parte funciona que, por sua vez, dá o segmento a ser seguido como o Ministério Público, o Poder Judiciário e a Polícia Federal, esta última instituição classificada e coroada como a mais eficiente instituição nacional.

2.2. Mutatis mutandis, esses órgãos não têm a função de demonstrar quais diretrizes devem ser seguidas. É competência única e exclusiva do Poder Executivo que infelizmente, atualmente, não tem Chefia neste apontamento.

Não há Presidencialismo sem presidente. Recente pesquisa aponta que a preocupação atual dos cidadãos brasileiros é com o crime de corrupção, que vem assolando o País; dados investigativos que afetam o Palácio do Planalto e o Congresso Nacional, causando mal-estar e incerteza tanto à sociedade quanto à economia como, também, ao Direito. A Presidência atual - temporariamente afastada - não conseguiu maior comunicação com a Nação; se concentrou somente em ajustes fiscais, quando tantos enfoques administrativos necessitavam melhorias; dentre as metas emergenciais, a da PEC do Teto dos Gastos n. 241 (limite e transparências nos orçamentos). A PGR entende que a PEC seja classificada como inconstitucional.

Existe notório embaraço entre o Poder Constituinte e o Poder Constituído; no Poder Legislativo, o sistema recursal em processos político-jurídicos é de morosidade inaceitável. São urgentes reformas, no intuito de se evitar descontentamento aos brasileiros

falando a língua tupi-guarani em parâmetro ao idioma português, além de definir e marcar, geograficamente, todo o território brasileiro. Os índios guaranis tinham a própria Religião e ritos característicos de suas tribos, acreditavam em Deus e não eram guerreiros por natureza, motivo de sua exterminação e mais de 20 mil escravizados tanto por "bandeirantes" quanto pelos jesuítas espanhóis. O desbravamento do território brasileiro tem saldo devedor aos índios, verdadeiros heróis sem estátuas. A primeira bandeira, comandada por Pêro Lobo, partiu em 1 de setembro de 1531, para nunca mais voltar. Em 1639, holandeses invadem a área atual de Pernambuco, mais tarde expulsos pelos "bandeirantes" e índios e de 1642-1647, Antônio Raposo Tavares se torna o último dos "bandeirantes". Ele chegou ao Brasil em 1618 e foi o homem que mais trabalhou no Brasil-colônia junto a Fernão Dias Paes Leme. 
que têm cidadania. Enfim urge novos diplomas legislativos. Lembre-se que corrupção tem histórico em grande parte dos demais países, a exemplo dos EUA como, também, na Inglaterra, mas extremamente corrigidas as mazelas nestes Estados.

Neste século, desnecessária a imposição ao voto obrigatório nas eleições democráticas à população que amadureceu; não há o por quê da proteção a menores de 18 anos que praticam furtos, roubos e assassinatos dos mais cruéis. Um quadro de retorno à barbárie dos tempos antigos. No ranking mundial da Educação, o Brasil está entre os dez piores índices do mundo na área educacional, impedindo os jovens de baixo rendimento acesso a níveis superiores.

O Plano Nacional de Educação, composto de 21 metas em todo o território nacional, por falta de investimentos, não foi cumprido, a exemplo dos programas de maior admissibilidade de professores na rede educacional ou o de incentivo, com a colaboração dos pais, à frequência de crianças em aulas semanais.

Há pequenez concordância quanto às penas alternativas da lei, tornando-se sério problema social o benefício da progressão de cumprimento penal. Desde 1984, não há sistema agrícola e o cumprimento do regime aberto passa a ser o de prisão domiciliar, porque o Estado não atende às alternativas da lei e, sem controle, torna-se extremamente ineficaz.

A premissa final é a de que o Povo brasileiro não suporta mais os desvios da Constituição e deveres de seus representantes. A classe política envelheceu em parâmetro à sociedade que, por sua vez, se modernizou. Na atualidade, a classe política não representa mais a sociedade.

A liderança política é imperiosa, crível se composta por homens de alto nível e perfil acadêmico, com dominância em conhecimentos sociais, os quais devem construir e demonstrar projetos ao desenvolvimento educacional, econômico e social e na criação de agenda forte que tenha, como foco primordial, a educação dos jovens. Homens fortes são aqueles que sabem cuidar dos eleitores; líderes investidores para demonstrar e dignificar os lugares que ocupam, por meio do voto popular; o contrário - governantes despreparados -, não passa de trapaça político-eleitoreira, de resultados maléficos e catastróficos ao desenvolvimento do País.

Trata-se de análise de Estado próspero que abriga jogos internacionais (Olimpíadas/Paralimpíadas e Copa do Mundo) e que discrimina por pequena parecla da sociedade seus integrantes, atacando-os com injúria os afrodescendentes, lembrando que a raça negra brasileira, devido ao clima e às águas, é uma das mais belas do nosso planeta e $51 \%$ da população brasileira.

Reflexão e consciência são temas que temos de ter: a de que somos brasileiros com rica miscigenação entre brancos, negros e índios, louvando as ex-escravas mães negras - raptadas de tribos sul-africanas como as de Guiné-Bissau, Nigéria, Angola e 
Moçambique pelos portugueses - colaboradoras no aleitamento dos filhos dos senhores feudais, como ensinava o ex-senador Darcy Ribeiro, um dos mais brilhantes cidadãos, nascido no Rio de Janeiro e profundo conhecedor da miscigenação do Povo brasileiro. Recorda-se que o abolicionista Joaquim Nabuco asseverava, em seus discursos, que o passado da escravidão iria permanecer por muitos anos. A África é a mãe do homem, cuja saga dos afrodescendentes se iniciou com o tráfico trazido pelos portugueses, lembrando que a beleza do Barroco foi construído por eles no Governo imperial.

A liberdade de expressão é símbolo da Democracia, veementemente respeitada pela maioria dos cidadãos; todavia, há limites à extrapolação: líderes em pronunciamentos públicos à Mídia muitas vezes se encontram em desconforto. Atletas da Federação Nacional de Futebol, aplaudidos pelo mundo esportivo, atrizes e apresentadoras de TV são gratuitamente ofendidos em pleno exercício de sua profissão ou pela Internet/ WhatsApp, veículos de comunicação da massa popular, na atualidade, com mais de 100 milhões de usuários. Cita-se a inesquecível cena da torcedora gaúcha em ginásio esportivo - gritando a expressão macaco - a um jogador de time de futebol que atuava em campo. Acredita-se que, além de punida, ela deveria se socorrer da Psiquiatria. E ensiná-la o conteúdo da Lei Áurea e da Lei Afonso Arinos, criada pelo ex-senador Afonso Arinos de Mello Franco, em 1951.

Enfim, o racismo se faz presente em mentes doentes; com uma diferença: neste caso, existem crimes como os de injúria/racismo; todavia, aos gays não há proteção jurídica, porque não existe contemplação no Código Penal/Contravenção Penal o crime de homofobia que necessita, por sua vez, de políticas públicas ao seu combate. O Estado tem de disponibilizar meios mais eficientes nestes casos específicos de agressão.

2.3. A situação do aposentado e do idoso em hospitais, repartições públicas, bancos, transportes coletivos é lamentável. O motivo? A falta de investimento e aparente abandono nas áreas Educação e Assistência Social, obedecendo-se o Estatuto do Idoso, Lei $n$. 10.741, de $1^{\circ}$ de outubro de 2003, promulgado no Governo Luiz Inácio Lula da Silva. A recomposição do Estatuto da Criança e do Adolescente no intuito maior de alinhamento de compreensão, ou seja, a de o menor ser educado e entender que não pode matar, lembrando também, ao ensejo, de que o Estatuto da Família está sendo apreciado no Congresso Nacional.

2.4. Desde os anos 60, o efeito da indústria vem prejudicando o meio ambiente e as reflexões do caminho entre a Realidade e a Natureza não acontecem, lembrando que mais de 400 espécies de animais foram extintas no século passado.

Enfim, inobservância à falta de respeito e do olhar à população e não a si mesmos, uma vez o Escândalo da Petrobras, que deu origem à Operação Lava-Jato (nome dado devido a descoberta de falcatruas em posto de gasolina) como, também, a 
Operação Mensalão ofendem desde o menor de idade - que almeja viver no futuro em um País melhor - aos que têm plena cidadania.

A maior estatal brasileira, a Petrobras, foi vítima de uma quadrilha composta por políticos e empresários, de projetos e investimentos irrealistas, daí a vida brasileira ser uma verdadeira coleção de momentos inesquecíveis.

Dentre as prerrogativas do combate à corrupção, acredita-se, dentre elas, o do fim do foro privilegiado (foro prerrogativo) às autoridades com base no Distrito Federal; por exemplo, a criação de Vara federal de perfil exclusivo no intuito de extinção a esses crimes que assolam o País. A última palavra seria do Supremo Tribunal Federal. Outro exemplo, o enxugamento ao sistema recursal que prolonga demasiadamente processos deste objeto: a corrupção. A morosidade nos processos é pauta campeã nas reclamações da Ouvidoria Nacional de Justiça. Enfim, um sistema desfuncional, ou seja, não-funciona.

Os países da América Latina estão em recessão, cuja dor cai sempre aos que estão embaixo; "bicho-papão" são dois: o Fundo Monetário Internacional (FMI), Banco Mundial e os bancos centrais (exemplo, o Banco Central norte-americano (Fed) depois de 8 anos de juros zero vem a elevá-lo, causando desequilíbrio e sério impacto no câmbio mundial). O Brasil passa por um período delicado desde 2014, havendo no ano 2015 pedido de impeachment da Presidência pela Oposição. ${ }^{12}$

São fatos tristes, uma vez não haver nenhum lado glorioso para toda a União, somente situação agravada. Neste ano, a análise do rito do impeachment para a sua efetivação ou-não.

2.5. Estado de Direito é um Estado de normalidade, não há nacionalidade fora do processo legal; fora da normalidade e da institucionalidade não há Direito. Os fatores que condicionam a Política brasileira atualmente são perversos, desde o Poder Executivo, passando pelo Senado e pela Câmara dos Deputados, uma vez os presidentes, das duas últimas Casas se encontrar qualificados em processos de investigação pela ProcuradoriaGeral da República (PGR) pelo eminente procurador Rodrigo Janot Monteiro de Barros.

12 Artifícios econômicos chamados de "pedaladas", atingem a Lei de Responsabilidade Fiscal, criada a dezesseis anos e que exige transparência praticados pelo Governo Federal provocaram um desastre econômico, servindo de argumento à Oposição em reivindicar política e juridicamente o impeachment da presidente da República. Recorreu-se até à última instância quanto aos ritos, para solucionar a tramitação, ao Supremo Tribunal Federal (STF) por meio de seus 11 (onze) ministros, cada um com seu conceito peculiar, apresentando seus pareceres. Enquanto isso, em parâmetro, economistas que têm sido nada mais nada menos do que meteorologistas, por seu lado, tentam mostrar ao País como evitar esta tempestade, fazendo com que o ex-presidente e sociólogo Fernando Henrique Cardoso se pronunciasse por meio da frase: "o País está como um trem descarrilado". O maior Tribunal do País (STF) tem como exercício uma Corte de constitucionalidade que, por sua vez, tem de se ater às complexas tramas de relações políticas, econômicas, jurídicas, valorativas, fáticas de seus julgamentos, complexos pela própria característica da Constituição Federal. E é por isso, mais do que em qualquer outra atividade, necessário que o Tribunal Constitucional examine até que ponto um determinado julgamento pode ou-não causar danos à sociedade. 
Aponta-se, finalmente, que a crise brasileira não está em consonância com a crise internacional. Quanto à empresa estatal Petrobras, orgulho do Povo brasileiro, há incerteza quanto ao prazo de sua recuperação como, também, ao seu futuro, uma vez portadora de débito classificado como um dos mais altos do comércio internacional, um recorde dado o crime de corrupção nela instaurado e que infelizmente a assolou negativamente, dando origem à Operação Lava-Jato e congêneres. O caminho da recuperação provavelmente será muito longo, o que se otimiza - com muita fé - pela imediata volta ao seu desenvolvimento anterior. Trata-se, enfim, da maior estatal do País!

\section{Momentos marcantes nos últimos anos no País}

O Seminário Roma-Brasilia, de 1988, em Brasília. Nele, a comemoração ao Centenário de Dom Bosco que induziu a reforçar o estudo dos aspectos proféticos da tradição romana e brasileira e a segunda outra novidade é correlacionada com a primeira que consistiu no estudo comparativo entre a Roma antiga e a Roma "americana". Esta comparação parece necessária quanto aos estudos jurídicos, uma vez abordar cidadania, municípios e instituições nacionais, correspondentes aos fatos histórico-religiosos, cujo objetivo da comparação se propôs aquele Seminário e o mais evidente é o de que a centralização do Poder e a miscigenação das culturas se caracterizam seja na Roma antiga que primeiramente foi República e depois Império; seja no Brasil, primeiro Império e depois República.

Assim, desde a origem, a essência do Imperium e, portanto, do Direito (Ius) do povo romano consiste na superação de barreiras étnicas, lembrando, conforme Haroldo Valladão em Le Droit Latino-americano do Asylum, aberto por Rômolo no Capitólio com a finalidade de acolher os homens livres e os escravos como cidadãos (Tito Livio $I, 8,5)$, totalmente coerentes com o princípio são a política da cidadania e a liberdade, enfatizando, em particular, a eficácia jurídica das manumissões, as quais fazem do escravo não-somente um homem livre, mas um cidadão.

O desenvolvimento da ideia do Império é iniciada no País com a Teoria do Quinto Império, elaborada pelo padre Antonio Vieira, um jesuíta defensor dos índios no século XVII e depois com as reflexões históricas sobre as profecias bíblicas de Sebastião da Rocha Pita, Autor do I Tratado Político, início do século XVIII.

Em saldo positivo, a mostra de que América Latina e Europa são unidas não-só pela Religião e idiomas como, também, pelo Direito e pelos povos migrantes. Existe porém uma diferença ainda maior que se sobressai ao se considerar a História do Direito e o da imigração no País: enquanto na Europa a unidade e a integração dos povos, antiga e medieval, é fracionada pelos Estados nacionais, na América Latina é 
principalmente aonde exista a tradição jurídica universalista como instrumento na busca de um novo mundo, no qual se fundem as diversas Nações.

Novamente 1988, a Assembleia Nacional Constituinte deu ao Povo brasileiro uma Constituição Federal, promulgada em 5 de outubro, na qual se reconhece o valor jurídico dos costumes indígenas (os índios estão cada vez mais vulneráveis, uma vez seu habitat ser invadido pelo homem branco) e que, estabelecendo o Princípio da Cooperação entre os Povos põe como objetivo da República a integração dos povos da América Latina:

São reconhecidos aos índios sua organização social, costumes, línguas, crenças e tradições, e os direitos originários sobre as terras que tradicionalmente ocupam, competindo à União demarcá-las e fazer respeitar todos os seus bens. (art. 231).

O Seminário Roma-Brasília, de 1989, tratou da tradição jurídica romana e as instituições indígenas. Os seminários de 1992 (Direito da Integração: Tratado de Roma e Tratado de Asunción); o de 1994 abordou a Cidadania e Integrações Continentais e Informática Jurídica.

Os seminários dos anos 90 centraram a atenção sobre os grandes problemas jurídicos derivantes da economia mundial e da ecologia, considerando a integração latinoamericana como possível resposta jurídica ao desafio da globalização.

Participação no Fórum do Mercado Internacional de Davos (Suíça), com várias pautas temáticas, além da Economia Internacional: Globalização, Terrorismo, Refugiados e Clima Ambiental, dentre elas, o aquecimento global. ${ }^{13}$

13 O mais novo ingrediente sem sabor, amargo e difícil de ingerir, encontrado na Europa e nos EUA, é o terrorismo, oriundo de correntes ideológicas muçulmanas, provocando desconforto, descontrole emocional e insegurança no mundo inteiro. Dos mais significativos e inesquecíveis citam-se os do jornal satírico Charlie Hebdo com a morte de editores e articulistas famosos e o do Café, Bar e Restaurante Ba'ta,clan (Paris) com a morte de 120 cidadãos franceses e estrangeiros. Na Data da Queda da Bastilha, 14 de julho, novo ataque em Nice, Côte D'Azur na Riviera francesa, com consequência de 84 mortos e 202 feridos, muitos em estado grave, provocado pela condução de caminhão alugado, dirigido por Mohamed Bouhiel, de dupla cidadania - franco-tunisiano -, reivindicado em nome do Estado islâmico. Os atropelamentos e mortes atingiram multidão que assistia exibição de fogos artificiais em comemoração à data histórica na orla da Avenida Passeio dos Ingleses, a principal da cidade. Na Normandia, Norte da França, padre é morto por terroristas provocando comoção no mundo. Ele pertencia à Igreja católica de Rouen e nela rezava missa. $\mathrm{O}$ Governo francês de François Hollande torna-se pressionado pelos ataques de grande impacto acontecidos em pouco tempo. Em San Bernardino (EUA) a morte de dezenas de crianças inocentes, tragédia causada por casal de origem muçulmana. Pouco tempo depois, em Orlando, ataque à Boate Pulse, causada por fanático classificado como pertencente ao grupo denominado "lobo solitário" pela Psiquiatria Internacional. Nascido em Nova York, filho de afegãos, Omar Mateen, que se autodefinia como "soldado islâmico" assassinou 49 pessoas e mais de 50 ficaram feridas no interior da casa noturna de perfil LGBT. Antes desse quadro, a capital da Bélgica, Bruxelas e também capital da União Europeia, UE, atacada por terroristas muçulmanos, matando frequentadores de bares e restaurantes. A Turquia vem sofrendo frequentes ataques do Estado islâmico e do grupo curdo separatista TKK - que há 30 anos luta internamente - em cômputo de seis 
Participação em dezembro de 2015, na ECO-21, acontecida em Les Bourges, Paris (França), com medidas para assegurar propostas a um acordo do não-aumento maior de $2^{\circ} \mathrm{C}$. No fórum, a participação de ministros do Meio Ambiente de 192 países, além de meteorologistas convidados pela ONU. O intuito não avançou muito, propostas foram catalogadas; todavia, os resultados foram insuficientes e injustos aos países pobres do planeta, dado o Capitalismo, vindo ao encontro da assertiva de León Duguit: "A justiça não é uma ideia racional, absoluta, revelada pela razão. É um sentimento próprio da natureza humana". Mesmo porque, o Capitalismo é um sistema corrupto pela própria natureza.

\section{Conclusão \\ 4.1. O Catolicismo}

Com os conceitos históricos e fundamentais, procura-se mostrar em consciência a importância da Religião católica, por meio de sua dificílima trajetória, permitindo aos cristãos primitivos percorrer caminhos em busca de disseminação aos Ensinamentos de Jesus Cristo; punidos sem julgamentos e sob cruéis perseguições em episódios da História da Humanidade, enfatizando o da Inquisição.

Os estudiosos da Religião não se enquadram, atualmente, nos Ensinamentos dos quatro Evangelhos canônicos, desde os achados da Coletânea Nag Hammadi, 1945, no Egito como os Evangelhos de Felipe, da Verdade, de Tomé (o mais diferenciado), os 114 provérbios de Maria Madalena, nascida em Magdala, onde Jesus a conheceu, tornandose sua confidente e eleita o apóstolo dos apóstolos ou os Evangelhos dos Oráculos de Maria, a Santa Mãe; os Evangelhos de Thiago e até recentemente o Evangelho de Judas Iscariotes e o de Tadeu (significado de gêmeos); por último, Evangelho de Pedro, em

violentas ações de terror, sendo o último, causado por três homens-bomba estrangeiros oriundos da região russa do Cáucaso: Quirguistão e Uzbequistão, acarretando a morte de 46 cidadãos e 236 feridos. A ação ocorreu no Aeroporto Atatürk Havalimani, terceiro maior aeroporto europeu na rota Europa/Ásia, Estreito do Bósforo. A ordem democrática turca ultimamente não tem sido respeitada e uma das mais belas cidades históricas da Humanidade, Istambul, se torna vulnerável, cabendo ao Governo turco de Recep Tayyip Erdoğan, um dos líderes mais controversos da História turca, e demais países-membros europeus maior reforço na segurança internacional. A Turquia é uma República laica com fortes instituições. No Brasil, por ocasião dos Jogos Olímpicos, surgem boatos de ataques, embora haja em terra brasileira baixa integração global. Por não fazer parte da coalizão internacional contra o grupo Estado islâmico (ISIS), o País não é alvo principal de terroristas, mas poderá ser o palco, dada a pulverização de atentados nesta guerra de fundamentalistas. O Serviço de Inteligência Brasileiro se utiliza, pela primeira vez, da Lei Antiterrorismo, com penas severas que podem variar de 3 a 15 anos, promulgada em março de 2016, no Governo Dilma Rousseff, após prisão de doze suspeitos convertidos à lealdade do ISIS, depois de serem monitorados pelas redes sociais (Operação Hashtag) em cidades de vários Estados da Federação brasileira. Registra-se que o Brasil é a antítese da cultura islâmica por ser povoado de gente alegre que aprecia o Carnaval, dança e música maliciosas, comportamentos avessos ao regime comportamental islâmico. 
língua copta, compondo todos eles os chamados Evangelhos Apócrifos, apagados da face da Terra.

Mesmo que se consiga ser apenas racional e experimental não se deve deixar influenciar pela Religião, uma vez cada um de nós obter o livre arbítrio; uma escolha estritamente pessoal. Exemplo, Maquiavel: ele foi religioso mesmo desejando ser única e exclusivamente racional e experimental, porque sentiu que, destruindo o mito de religiosidade no qual os italianos estavam emparedados, ele serviria à causa do Direito e da liberdade, dos princípios que enobrecem a alma humana. E esse resultado é justamente a essência da Religião. Naturalmente, Maquiavel nunca foi patético e nem a sua modéstia nem o seu orgulho o deixaram sê-lo.

Na Religião católica, desde o comportamento, usos e costumes dos cristãos primitivos, prevalece a modéstia, a liberdade, a igualdade no intuito de se fazer integrante à população de uma Nação onde a vida, dentro dela, seja assegurada, lembrando que Maquiavel é um dos apóstolos da ideia de liberdade, além de o primeiro mestre da Ciência Política; basta ler “O Príncipe”, que começara a escrevê-lo em 1513 e acabado em 1516. Uma das suas maiores e significativas assertivas é a de que quando se expressa "para termos a justa medida de um homem precisamos olhá-lo no seio de sua família”.

4.1.1. A estrutura familiar é o argumento mais eficaz, a premissa maior da Religião católica, desde o nascimento de Jesus, seu Pai José e sua Mãe, a Santa Maria. É a partir desse apontamento, a família, que a Igreja católica se embasa como a mais devota e procurada pelos habitantes deste planeta, embora haja problemas internos na sua constituição e composição.

O tópico materfamilia é enfocado no Cristianismo, por meio da imperatriz Helena, mãe de Constantino I, imperador romano convertido que se consagrou vitorioso na Guerra de Mílvia, ao verificar nos Céus a silhueta branco-acinzentada do símbolo da cruz. A cruz, antes de referência cruel, torna-se para os cristãos a magia da fé e a marca sagrada do valor da Igreja, uma organização jurídica fundada por Jesus Cristo.

Neste período, a Igreja católica se acoberta de assunto privado e passa a ser uma comunicação direta e individual com o Deus Único, alheia a toda manifestação social, desde o Liberalismo que é o de exigir de cada indivíduo o esquecimento de sua condição cristã na Assembleia ou no Parlamento, para depois recuperá-la, principalmente quando estiver no recinto dos templos da Igreja católica.

Conforme comenta com maestria o filósofo espanhol Rafael Llano Cifuentes:

Nega-se toda possível ordem objetiva social ou jurídica querida por Deus. E fazendo a Deus à imagem e à semelhança de cada homem, cria-se também o Reino de Deus no mundo ao sabor dos próprios gostos. 
4.1.2. Ao Estado só interessa a pessoa humana, enquanto cidadão temporal e não enquanto cidadão fiel às determinadas crenças religiosas que têm convicções particulares, totalmente sem relevância à vida pública. E pela mesma razão, a Igreja deve ser considerada como mera associação sem direitos especiais e com a qual o Estado deverá ter completa independência, excelente harmonia e absoluta separação, uma vez ambas as esferas possuírem finalidades diferentes ou linguagens próprias, individuais.

Mas nada impede ao Estado em ouvi-la em certas circunstâncias sociais e políticas e vice-versa e é o que acontece no século XXI, não-só com a Igreja católica; outras, por meio de suas fé e linguagem diferentes têm participado à conduta de um ser humano mais caloroso e receptivo, principalmente com relação aos refugiados, emigração em massa, porque fogem de seus países de origem, cujo exemplo são seus novos semblantes encontrados em águas geladas, a exemplo trágico da cena emblemática da criança morta na praia do Mar Egeu recolhida por membro policial da guarda costeira mediterrânea.

Refugiados a pé, pedintes na busca de saciar a fome ou imediato socorro: o semblante dos refugiados que comove cristãos e não-cristãos. Segundo estatísticas da Organização das Nações Unidas (ONU) mais de 65 milhões de pessoas, 50\% crianças, se deslocaram de suas terras de origem, principalmente da Síria (ênfase à destruição concentrada de Aleppo), Afeganistão e Somália por medo de perseguições religiosas e de ataques regionais políticos. Nota-se que a estatística ultrapassa a estimativa da II Guerra Mundial! Os que podem e devem salvar a vida desses seres humanos são os próprios seres humanos, a exemplo da primeira-ministra da Alemanha, Angela Merkel. São vidas que não podem ser esquecidas e têm de ser salvas em termos humanitários, ao encontro dos fundamentos da Corte Internacional dos Direitos Humanos.

\subsection{O Direito brasileiro. A Política brasileira}

4.2.1. Enquanto os Reis europeus pediam perdão e autonomia para continuar a comandar seus Estados a Napoleão Bonaparte, D. João VI fugia para o Brasil, trazendo junto à Corte mais de 18 mil pessoas, as quais deram início à precária legislação no intuito de impulsionar a nova colônia. O Direito brasileiro tem raízes no Direito português (as Ordenações), no Direito italiano, francês, alemão e inglês; todavia, é embasado pelo Direito Romano em parâmetro aos EUA, anglo-saxônico. O Direito brasileiro foi constituído para chegar a um leque jurídico, por meio de diplomas eficazes e atentos à plena democracia.

O País, desde a sua descoberta, foi respaldado e dignificado pelos povos primitivos e colonos que nunca deixaram de sustentar e elevar a área Agrícola em potência notável; todavia, deve-se ajustar na sustentabilidade e tecnologia. Já a Agropecuária é o mercado que mais cresce. 
Dada a incompetência política há décadas - no cumprimento dos deveres de casa -, a contribuição para que o País deixasse de ser a maior potência nesta área; salvação ao progresso em mercado que comercializa bilhões de toneladas de soja ao Exterior. A maioria oriunda do Estado do Rio Grande do Sul. Os produtores agrícolas nunca deixaram de ser os maiores parceiros ao desenvolvimento nacional. Não se descarta a Agropecuária, uma vez, atualmente, cerca de 158 países se abastecer, por meio da importação do frango brasileiro. A garantia é a de 4 milhões de empregos ofertados, dada significativa exportação.

4.2.2. Nos séculos XX e XXI, o Direito brasileiro apresenta modelo saturado em determinadas áreas jurídicas, mediante situações embaraçosas sentidas em todo o País, envolvendo os diplomas do Direito do Trabalho e da Previdência Social, regidos pela Consolidação das Leis do Trabalho (CLT), Decreto-Lei n. 5.452, de 1 de maio de 1943, assinado pelo ex-presidente Getúlio Vargas, no Rio de Janeiro (em comemoração do $122^{\circ}$ ano da Independência e $55^{\circ}$ da República), Código Penal, Decreto-Lei n. 2.848, de 7 de dezembro de 1940 (enfatiza-se a maioridade penal), Direito Processual Penal; urgentes reformas nas áreas do Direito Econômico-Financeiro e em diversas legislações dos Direitos Humanos.

E neste ano, a Conferência Nacional dos Bispos do Brasil (CNBB) junto ao Ministério da Justiça, Ministério Público Federal (MPF) e o Instituto dos Advogados (IA) reuniram-se em análise ao atual Governo Dilma Vana Rousseff em pauta com itens sobre a intolerância política e aos preconceitos; por meio de cartas, pedem pacificação ao povo.

4.2.3. Embora área jurídica nova, o Direito Ambiental tem pouca rigorosidade; outro Estado mais rigoroso puniria severamente a catástrofe de Minas Gerais (enfatiza-se o episódio da Mineradora Samarco que obteve rachaduras na Barragem do Fundão, no Distrito de Bento Gonçalves, vinculada à Companhia Vale do Rio Doce, provocando um tsunami de lama com danos incalculáveis em Mariana, Minas Gerais e centenas de moradores desabrigados, dezenove mortes, sendo um corpo até hoje não achado e sem se computar as mortes de animais).

4.2.4. O respaldo maior à estruturação do Direito brasileiro veio com a criação dos cursos jurídicos, por meio da fundação da Faculdade de Direito de São Paulo e a de Olinda (depois Recife), ambas em 1827, por Lei promulgada pelo imperador D. Pedro I, em 11 de agosto, após série de debates parlamentares acontecidos no ano anterior, 1826.

A criação dos cursos jurídicos obedecia a um imperativo político da maior importância, que era o de propiciar a formação de uma burocracia administrativa nacional, assim como dos quadros políticos da nova Nação, uma vez que, com a independência do País, não era desejável que os bacharéis brasileiros continuassem a se formar em Coimbra, Portugal. 
Independente de Portugal desde 7 de setembro de 1821, fato conhecido como "O Grito do Ipiranga" liderado por D. Pedro I, o Príncipe Regente e futuro imperador do Brasil e Rei de Portugal - com apenas 24 anos de idade que completaria um mês depois, no dia 12 de outubro -, torna-se o País uma República, em 1889.

A República resulta de fatores como a questão federal, diretamente ligada ao crescimento da influência do setor cafeeiro na economia nacional. Outro fator foi o da questão religiosa nascida com a Bula do Papa Pio $I X$, a qual proibia a presença de maçons em congregações católicas, cuja decisão foi vetada pelo primeiro-ministro Visconde do Rio Branco, originando cisões entre o Estado e a Igreja que deixa de apoiar D. Pedro II nos momentos finais do seu Reinado.

São Paulo cresce ao redor da Faculdade de Direito, quando já se iniciava manifestações de trabalhadores realizadas no Largo de São Francisco, cujo comício em respaldo à greve dos operários da Companhia Paulista de Estradas de Ferro (CPEF) foi liderado por Ricardo Gonçalves, estudante da Faculdade e um dos primeiros socialistas brasileiros. Ele se suicidou por desilusão amorosa aos 28 anos de idade.

Em 1907, Euclides da Cunha, à época considerado fenômeno cultural com a publicação de Os Sertões denuncia o massacre de Canudos e pede apoio a Castro Alves, uma vez o republicano estar indignado com as atrocidades cometidas pelo Exército brasileiro.

No ano de 1909 advém a Campanha Civilista, ocorrida no início da primavera, quando estudantes cariocas saem às ruas para festejar a efeméride e são dispersados com violência tanto pela Polícia quanto pelo Exército brasileiro. No confronto, a morte de dois estudantes, dando início a tumultos em vários Estados, incluso São Paulo que se solidariza; o fato ficou conhecido como Primavera de Sangue, sendo o estopim da então recém-lançada Campanha Civilista, de Rui Barbosa; aqui o civilismo mais retórico do que real.

Assim, a nova classe social iniciava reformas no País. A Campanha Nacionalista capitaneada por Olavo Bilac nasce em decorrência da I Guerra Mundial que motiva, por sua vez, um surto nacionalista. As Nações da periferia do Capitalismo começam a tomar consciência de sua marcante inferioridade.

Olavo Bilac - poeta, escritor, político republicano e filósofo - se lança à Campanha, tendo na pauta eleitoral a obrigatoriedade da prestação do serviço militar, realizando conferências em vários Estados, inclusive na Faculdade de Direito de São Paulo. Uma antiga Província paulistana que elevou o Brasil a um patamar considerável, cuja evolução nacionalista veio desta cidade. E nos recintos da Academia de Direito, em 9 de outubro de 1915, Olavo Bilac se pronuncia, dando viva alma ao País, por meio do famoso discurso Oração aos Moços. Época do inventor Santos Dumont, um dos homens que o país tem orgulho junto ao seu 14-Bis e à Aviação na comunicação social mundial. 
4.2.5. O ano de 1922 é marco na História do Brasil por trazer o início do Movimento Tenentista com o Levante do Forte de Copacabana, em 5 de julho, duramente reprimido pelas forças governamentais, além da fundação do Partido Comunista (PC), mais tarde Partido Comunista do Brasil (PCdoB), e que sela o declínio do anarquismo, além de consolidar o ascenso comunista no Movimento Operário.

Registra-se, também, que 1922 foi o ano da Semana de Arte Moderna, de 13 a 17 de fevereiro, no Teatro Municipal de São Paulo, acarretando grandes debates no meio cultural do País.

Com o declínio da economia cafeeira, a transferência do Poder econômico para os atacadistas e exportadores, em detrimento dos produtores, cuja decadência se iniciava desde o início do século XX e foco da base social do Partido Republicano Paulista (PRP), o qual não teve êxito, motivado pela chegada da Revolução de 30, que o liquida.

Em 3 de maio de 1933, Getúlio Vargas realiza eleições para a Assembleia Nacional Constituinte e pela primeira vez no País o voto é secreto; as mulheres podem votar e ser votadas, sendo Carlota Pereira de Queiroz eleita constituinte: a primeira mulher eleita democraticamente no Parlamento. No ano seguinte, 16 de julho de 1934, é promulgada a nova Constituição e, no dia seguinte, pelo voto indireto dos constituintes, Getúlio Vargas é eleito presidente da República até 3 de maio de 1938.

Ao mesmo tempo à dominância de Vargas no Brasil, na Europa o nazismo e o fascismo estão cada vez mais fortes, época em que Adolf Hitler ganha poderes absolutos do Parlamento alemão para a construção do III Reich.

Getúlio Vargas volta ao Poder: consolida a situação dos trabalhadores, por meio da expedição aos que trabalham da Carteira do Trabalho e da Previdência Social (CTPS); todavia, se suicida em 1955. Ele foi o fundador do Estado Novo, dando margem à criação dos sindicatos e à expansão do País.

Em setembro de 1951, iniciada na Faculdade de Direito de São Paulo, nasce a Resistência contra depravação política no Brasil, quando os estudantes, reunidos em assembleia nos porões do Centro Acadêmico XI de Agosto e no Auditório da Sala dos Estudantes, lançam manifesto, alertando às autoridades para o perigo que representa a crescente corrupção política. No ano seguinte, 1953, nova revolta do povo e dos estudantes contra o Governo Federal similar à dos tempos do Estado Novo.

Nos anos 60, após a Gestão do fundador da cidade de Brasília, capital do País, Juscelino Kubitschek de Oliveira, plataforma do futuro Governo Jânio da Silva Quadros à Presidência da República. O novo presidente tinha o hábito de se expressar por meio de "bilhetinhos", com os quais sacudiu o País. As mudanças do traje para enfrentar o calor de Brasília, a condenação das brigas de galo, a posição corajosa em relação à política internacional; tudo isso para trazer impacto à opinião pública e favorecer as mudanças sociais, que tinha em mente, prometidas durante a sua vitoriosa campanha. O presidente 
Jânio da Silva Quadros é um dos únicos líderes a ocupar as plataformas constitucionais do País: Presidência, Governança e Prefeitura, as duas últimas paulistas.

Segundo pronunciamentos de Vera Chaia em livro autobiográfico, referendado no final desta matéria "a imagem de político diferente e não atrelado às estruturas partidárias, construída por Jânio e reafirmada pela Imprensa, fez com que outros partidos políticos tentassem trazê-lo ao seio de suas agremiações”. Jânio Quadros tinha um perfil diferenciado até na linguagem, uma vez professor; criava palavras novas, enriquecendo o nosso dicionário e não admitia erros tanto no falar quanto na escrita. Um dos maiores estadistas que o País possuiu. Ele renunciou ao cargo de Presidência; morreu aos 75 anos de idade, em 16 de fevereiro de 1998.

4.2.6. O sucessor de Jânio Quadros, Jango Goulart, acusado de golpismo, foge ao Exterior. De 1964 a 1985, um período de ditadura militar. Em março de 1969, um decreto torna ilegal qualquer crítica dos atos institucionais, às autoridades governamentais e às Forças Armadas. A Censura (Divisão de Censura de Diversões Públicas da Polícia Federal (DCDP), extinto no final dos anos 80, proíbe a publicação de notícias sobre manifestações estudantis como, também, dos trabalhadores.

A Imprensa é posta sob a supervisão dos tribunais militares e a tortura contra presos políticos se generaliza. Nem a repercussão dos assassinatos dos jornalistas Vladimir Herzog e Alexandre Vannucchi Leme foi o suficiente para deter a fúria dos órgãos de repressão.

O grupo Balé Bolshoi, nos anos 70, companhia de dança da antiga URSS, é impedido, pela ditadura, de se exibir no País. O ministro da Justiça, Armando Falcão, inventa uma lei eleitoral, censurando as palavras dos políticos em horas gratuitas de propaganda na TV. Filmes como O Último Tango em Paris (EUA), protagonizado por Marlon Brando e Maria Schneider jamais poderiam ser catalogados às apresentações de cinema. Essas longas-metragens foram substituídas, por exemplo, pelo romance água com açúcar Sissi, a Imperatriz, protagonizado pela bela atriz Romy Schneider!

Em abril de 1977, o general Ernesto Geisel lançando mão do Ato Institucional n. 5 (AI-5), fecha o Congresso e anuncia um pacote de medidas, incluindo eleições indiretas para 1/3 do Senado Federal e para o Governo dos Estados nas eleições de 1978. Os novos eleitos são apelidados pela Oposição de senadores e governadores biônicos. Em 8 de agosto de 1977 o imortal e querido professor Goffredo da Silva Telles Junior reinvidica a Democracia, no Pátio das Arcdas por meio da Carta aos Brasileiros.

O general João Figueiredo foi o último presidente da ditadura que havia tomado posse, em 1979, ano em que a Anistia é aprovada, retornando ao País os exilados; os agentes dos órgãos de repressão são isentos de culpa, o que não impediu que o Estado fosse julgado pelos excessos cometidos contra a Oposição política. Em novembro de 1979 
é aprovado projeto de lei que institui o pluripartidarismo, com a extinção da Arena e do $M D B$ (únicos partidos); todavia, os partidos comunistas continuam na clandestinidade.

A redemocratização do Brasil acontece com a Emenda das Diretas-Já, liderada pelo deputado Ulysses Guimarães, e a eleição à Presidência da República, em 15 de janeiro de 1985, de Tancredo Neves, após 21 anos de ditadura, mas uma doença o impede de assumir; fato contestado até hoje no seio da sociedade. Pelo voto direto, eleito Fernando Collor de Mello, o mais jovem presidente eleito no País e nas Américas, aos 40 anos de idade.

O irmão do presidente eleito, Pedro Collor de Mello, dá entrevista à Revista Veja e no periódico acusa o tesoureiro da campanha, Paulo César Farias, conhecido como PC, de ser a eminência parda de um esquema de corrupção, de proporções inéditas na História da República brasileira que, mais tarde, é superada pelos escândalos da corrupção na Petrobras, (apelidada de Operação Lava-Jato). Seus sucessores Itamar Franco e José Sarney fracassam na conduta presidencial. Surge o movimento de impeachment. Quanto ao movimento de impeachment, este se perpetua no slogan "Fora Collor". A causa da morte de PC - encontrado morto em sua casa de praia ao lado de sua amante Suzana Marcolino - nunca foi esclarecida. Fernando Collor de Mello é afastado pela Câmera Federal (Ibsen Pinheiro preside o rito) e no Senado pelo impeachment, supervisionado pelo ministro Sydney Sanches. Ao término da Gestão Collor advém o financiamento das empresas público-privadas às campanhas eleitorais, uma vez, antes de 1992, estar proibido.

4.2.7. A conversão da moeda para "Real" veio na Gestão do ex-presidente e sociólogo Fernando Henrique Cardoso que havia sido ministro da Fazenda, quando o País se estabiliza. O ex-presidente FHC se concentra em sua Gestão mais para o lado da economia em parâmetro à reforma política; todavia, o Governo federal idealizou e triunfou trajetória satisfatória, por meio do sociólogo presidente junto à primeira-dama, professora Ruth Cardoso.

Neste ano, 2016, novo impeachment tem sido reivindicado pela Oposição; desta vez, à chefe atual do Governo, Dilma Vana Rousseff, de família originária da Bulgária.

Instaura-se a Comissão Especial do Impeachment no intuito de estudo da admissibilidade da acusação, presidida pelo deputado federal Rogério Rosso, PSD/Distrito Federal, com andamento de rito composto de dez sessões. Nestas sessões, as presenças dos juristas autores do pedido - Miguel Reale Júnior e Janaína Conceição Paschoal, ambos professores doutores desta Academia de Direito (FDUSP) e de Hélio Bicudo que pertenceu ao Partido dos Trabalhadores. Autores e membros contra-impeachment foram ouvidos pelos parlamentares. O advogado de defesa da Presidente afastada é o ex-ministro da Justiça, José Eduardo Cardoso, desta Academia de Direito (FDUSP). 
Aprovado o Relatório, remetido aos cuidados da Comissão Especial do Senado Federal composta por juízes que, neste caso, são os próprios senadores. Após a aprovação em Plenário do Senado Federal, o rito será presidido pelo presidente do STF, Enrique Ricardo Lewandowski, professor titular de Direito do Estado, desta Academia de Direito (FDUSP).

A exposição de motivos tem análise político-jurídica de suma importância para a admissibilidade; dentre elas, a do professor Fábio Medina Osório, presidente do Instituto Internacional de Estudos dos Direitos do Estado, do procurador do Tribunal de Contas da União (TCU), doutor Júlio Marcelo de Oliveira e do professor de Direito Econômico-Tributário José Maurício Conti, desta Academia de Direito (FDUSP).

À Relatoria coube ao senador Antonio Augusto Anastasia, do PSDB-MG, com brilhantismo decantado por todos os colegas pares do Senado Federal e debaixo de um jogo à preservação da estabilidade fiscal e monetária do País. Em maio, a presidenta é afastada por 180 dias.

Meses depois, maio/junho, o presidente da Câmara dos Deputados, Eduardo Cunha, também é afastado do cargo, acusado de evasão de divisas, falsificação de contas à Justiça Tributária Federal, além de indícios de recebimento de propina em contas bancárias na Suíça. Em julho, o presidente afastado da Câmara dos Deputados renuncia. De maneira democrática e parcimoniosa é eleito em $2^{\circ}$ turno o deputado Rodrigo Maia (DEM/RJ), $19^{\circ}$ presidente, depois da redemocratização, que ocupará o mandato-tampão até fevereiro de 2017.

Atualmente o presidente interino da República é Michel Miguel Elias Temer Lulia, diplomado pela Faculdade de Direito da Universidade de São Paulo com raízes de família originária do Líbano, mostrando a grandeza do Brasil em acolher imigrantes de todas as partes do mundo.

4.2.8. O Direito brasileiro é regido pela Constituição da República Federativa do Brasil (DOU, 5 de outubro de 1988 com 91 emendas); dentre a organização dos Poderes (arts. 44 a 135), o Capítulo IV: Das funções essenciais à Justiça (arts. 127 a 135) e na Seção I, do Ministério Público (arts. 127 a 130). Na União Federativa do Brasil, o Ministério Público compreende:

\footnotetext{
* Ministério Público Federal;

* Ministério Público do Trabalho;

* Ministério Público Militar e o

* Ministério Público do Distrito Federal e Territórios.
} 
O Ministério Público da União tem por chefe o procurador-geral da República, nomeado pelo presidente da República, dentre histórico de integrantes da carreira na Procuradoria dos Estados. A organização do Ministério Público decorre diretamente da Constituição Federal e no plano infraconstitucional há de se ressaltar a Lei Orgânica Nacional do Ministério Público, Lei n. 8.625, de 12 de fevereiro de 1993, assim como a Lei Complementar que estabelece o Estatuto Público da União.

Todavia, Ministério Público, Poder Executivo (regido pelo chefe do Estado brasileiro), Judiciário e Legislativo e o conjunto de normas jurídicas que compõe códigos diplomáticos são instituições de controle que têm funcionado perfeitamente, em consonância com o quadro atual de servidores composto de uma geração severa, diplomática e avessa à corrupção.

A Confederação Nacional da Indústria (CNI) contratou, em janeiro deste ano, pesquisa popular que aponta a corrupção no topo de males na preocupação dos brasileiros. No Brasil, há cidadãos que pegam a "jardineira” para chegar a longínquos postos de Saúde, enquanto a minoria vai ao trabalho de helicóptero!

4.2.9. A Lei Rouanet - criada no Governo do ex-presidente e sociólogo Fernando Henrique Cardoso, 2001 -, permite que pessoas físicas e jurídicas contribuam a eventos culturais; a compensação, o abatimento nos tributos da Receita Federal. Todavia, neste ano, a Polícia Federal e o Ministério Público desvendaram esquema de corrupção intitulado Operação Boca Livre. A organização criminosa - composta por cerca de catorze produtores culturais e artistas - agia há mais de quinze anos nesta captação. Eles se utilizavam desses recursos, destinando-os em projetos próprios; dentre esses produtores, um deles bancou o casamento do próprio filho em resort da luxuosa Praia Jurerê, Florianópolis, justamente em época de tecnologia de informação. Todos indiciados e presos.

Os eventos culturais são de suma importância à sociedade e à nova e futura geração: um desses eventos é a Feira Literária Internacional de Paraty (FLIP) em sua $14^{\mathrm{a}}$ edição anual que, por sua vez, agrega e apresenta vasta programação - intituladas "mesas" -, as quais são destinadas aos escritores e jornalistas a debates e análise de obras literárias como, também, a comentários e discussões do acervo em exposição. A Feira contempla a presença de escritores do mundo todo nesta cidade do litoral Sul do Estado do Rio de Janeiro.

A FLIP contribui muito à cultura do País, ao caminho educativo do incentivo à leitura, especificamente dos jovens, cuja maioria não tem o hábito de ler. Nesta última Edição, a visita da escritora russa Svetlana Aleksiévitch, ganhadora do Prêmio Nobel de Literatura, de 2015.

4.2.10. A corrupção se traduz por enriquecimento ilícito de agentes públicos; trata-se de furto aos cofres públicos. A maioria praticada por políticos que, 
por sua vez, têm foro privilegiado e este instituto não obteve êxito na História do País. Quando estes políticos corruptos são acusados, utilizam-se do sistema recursal, cujos processos jurídicos chegam a levar de 15 a 20 anos para serem julgados, caindo em objeto a se procrastinar com consequência final de prescrição.

Quanto à função da Operação Lava-Jato em suas dezenas de desdobramentos, vale a definição: uma Cruzada contra a corrupção, semelhante à Caixa de Pandora, uma vez que a cada dia aparece uma surpresa a ser investigada.

Em três anos - 2014/2016 -, o País está sendo redesenhado como ninguém conhecia, afetado por série de escândalos financeiros protagonizado por políticos, empresários e agentes públicos que estão no topo da cadeia alimentadora da corrupção, segundo Deltan Martinazzo Dalagnol, coordenador dos procuradores federais, nesta Operação. Embora condenados, a morosidade processual é campeã das reclamações na Ouvidoria do Conselho Nacional de Justiça.

4.2.11. Vive-se atualmente no País uma cinzenta nebulosidade em áreas jurídico-econômicas na busca de uma Ética que, por sua vez, é a busca de uma vida plenamente humana. O Ministério Público, por meio do porta-voz e coordenador dos procuradores, Deltan Martinazzo Dallagnol, lançou campanha no intuito de maior punição aos autores criminosos da corrupção no âmbito nacional/internacional, os quais sempre conseguem proteção em suas diversas corporações. A corrupção foi por décadas postergada e um jogo de grupos criminosos, afetando demasiadamente o País. No Congresso, como visto, Projeto Anticorrupção, elaborado pelo Ministério Público, composto de 2 milhões de assinaturas de cidadãos brasileiros, cujo propósito é o de dar maior valoração ao País, extinguindo corruptos e corruptores.

4.2.12. Dada a desaceleração mundial, desde 2008, o Brasil tem sido prejudicado economicamente, uma vez a estabilidade da dívida internacional ser fundamental ao crescimento; embora, também, outras potências ter contribuído à crise internacional, por meio de gastos internos excessivos, manipulação de câmbio internacional e outros. Inclui-se a China, pertencente ao bloco dos BRICS (Brasil, Rússia, Índia, China e mais recentemente África do Sul).

Lembra-se que o Brasil é enquadrado como grande potência agrícola e é a China (com o Produto Interno Bruto, PIB, de 6,9\%, dada a queda nas exportações, altos níveis de endividamento, maquiagem nos números da Economia e desaceleração na carteira imobiliária) que é dependente de nosso País, uma vez importar cerca de 40 milhões de toneladas de soja.

Ressalta-se aqui que o Mercosul, mediante os fatos econômicos e políticos, de fato, não ofereceu resultados, cujas regras têm de ser reestruturadas na área do comércio internacional. 
Computa-se, também, o Banco Central norte-americano que depois de oito anos de juros zero vem a elevá-lo. Nesse redemoinho, o Brasil se posiciona em índices de avaliação (apontado pelas agências avaliadoras de comércio e investimentos internacionais) muito baixo, calculados, por exemplo, pela Standard \& Poor's e Fitch Ratings, ONGs respeitadas pelos investidores internacionais.

Devido à falta de punição, no ranking da Transparência Internacional editada pela Alemanha, a reflexão e a percepção da corrupção, no setor público, ocupa o gigante País uma das mais baixas posições do mundo, sendo a Coreia do Norte e o Iêmen a ocupar as últimas posições.

4.2.13. A ONG Transparência Internacional - existente há 20 anos -, teve o intuito, neste ano, de compartilhamento de informações com a Operação Lava-Jato, beneficiando demais países estrangeiros. Destaca-se a presença do presidente da $O N G$ Transparência Internacional, José Carlos Ugaz Sánches-Moreno, do Peru, no mês de junho, com esta finalidade, procurando, inclusive, compreender a crise institucional no Brasil. Dos vários incidentes negativos, o mais recente é o da saída do Reino Unido do bloco da União Europeia, UE, (Brexit), contrariando a orientação do primeiro-ministro David Cameron que renunciou após plebiscito realizado pelo Governo inglês, aplaudido e ovacionado. A sucessora Theresa May vem a ocupar o lugar, prometendo em sua plataforma governamental construir um país melhor. Ela tomou posse, em julho, ao receber o mandato da Rainha Elizabeth II, no Palácio de Buckingham.

O embaixador do Reino Unido no Brasil, Alexander Ellis, exímio conhecedor do idioma português, em entrevista à Mídia nacional, afirma que nada mudará em nosso País, mediante o fluxo econômico, uma vez existir forte acordo bilateral, com a ressalva de que as regras internacionais sejam devidamente contempladas. Todavia, o fato se apresenta como imprevisível quanto ao futuro crescimento - ou-não - da economia global, atingindo países emergentes, incluso o Brasil.

\section{O Painel do Brasil neste século XXI}

5.1. No País, neste ano, chega-se a um patamar de 12 milhões de habitantes desempregados e nesse quiproquó acelera-se a dominância fiscal à volta da CPMF (imposto a ser cobrado em transação financeira tanto de pessoa física quanto jurídica), alarmando mais ainda a população que paga tributos/impostos dos mais exorbitantes do planeta. A pauta recessão/inflação tem esmorecido o trabalhador contribuinte.

Mister imprescindível rigoroso ataque ao sistema fiscal para que o Brasil volte a crescer, evitando-se, assim, o número de empresas em situação ociosa, por falta de investimentos e, consequentemente, ao bloqueio das demissões dos trabalhadores; principalmente aos que atuam em serviços de mão de obra, a exemplo da área da construção 
civil. Não é a Justiça do Trabalho, o Parlamento ou os sindicatos que geram emprego; este, é garantido pelos empregadores e empreendedores em sociedade que tenta novamente avançar para o crescimento. Enfim, uma legislação trabalhista retrógrada vigente que em nada auxilia o trabalhador.

O consignado, módulo financeiro de empréstimo - utilizado por grande parte dos servidores públicos e aposentados -, meta de sobrevivência emergencial orçamentária do trabalhador, incrivelmente nesses últimos anos obteve o sistema afetado pela corrupção, Operação Custo-Brasil - Operação esta comandada pelo procurador federal Andrey Borges de Mendonça, desta Academia de Direito (FDUSP) -, contribuindo à geração de inadimplentes e prejudicando as redes bancárias atuantes em todos os Estados da Federação.

5.2. Enquanto o mundo lamenta ataques terroristas, no Brasil são mortos mais de 1,4 mil pessoas por ano, atribuídos a crimes de banditismo; dentre eles, assaltos a mão armada com a conivência de menores de idade sem se mencionar o alto índice estatístico de ataques domésticos às centenas de mulheres (feminicídio), muitas assassinadas pelo próprio companheiro, porque o Estado não atende às leis mais severas. Embora em vigência há dez anos, a Lei Maria da Penha que leva este nome em homenagem à mulhercoragem de nome homônimo.

[No ano de 1983, em Fortaleza, Maria da Penha, ex-aluna da Universidade de São Paulo, sofreu atentado de morte, atingida por tiros de revólver, crime protagonizado pelo próprio marido, de nacionalidade colombiana - naturalizado brasileiro -, o qual simulou o crime alegando assalto à residência do casal. Tornando-se uma ativista, investigou a simulação fraudulenta do marido e recorreu à Organização dos Estados Americanos (OEA) que pressionou o Governo brasileiro em relação aos abusos de violência contra a mulher; na atitude de denúncia desta mulher corajosa e determinada, cria-se a Lei Maria da Penha. Atualmente, ela ocupa o cargo de conselheira no Instituto Maria da Penha.]

Premissa final: são medidas judiciais importantes, caminhos estes que toda mulher tem direito constitucional garantido na Legislação brasileira. Uma instituição republicana de proteção às mulheres do nosso País.

A última novidade é composta de dois itens: o da cultura do estupro coletivo, sendo a pauta de maior destaque na Mídia nacional. E o do linchamento, de ordem social, que tem aumentado assustadoramente por não haver Polícia devidamente aparelhada. Quanto ao primeiro, o Anuário Brasileiro de Segurança Pública aponta 47.646 casos de estupro, usado em hashtag, sendo banalização de total violência contra a mulher, justamente a elas que dão origem à vida humana. As políticas sociais do Governo Federal têm de ser mais rigorosas.

5.3. A exploração sexual de meninas como, também, o tráfico de crianças dada a vigilância e a rigorosidade da Polícia Federal Brasileira (FBI), instituição classificada 
atualmente como a melhor do mundo, diminuiu significadamente, em parâmetro aos anos 80/90, sendo a diminuição do primeiro item $67 \%$ e a do segundo, $80 \%$, segundo dados da Segurança Nacional.

A pena de morte não existe na Legislação brasileira; todavia, existe nas mãos de criminosos violentos, principalmente em atos de emboscada, os quais, munidos com armas de alto calibre, como fuzis ilegalmente importados, que se manifestam dolosamente ao descobrir vítimas que pertençam aos quadros da Polícia. Esses policiais são mortos, inclusive, em períodos de gozo de férias ou de folga na jornada de trabalho. $\mathrm{O}$ saldo: centenas de órfãos e viúvas! Enfim, nem a Polícia está isenta da violência.

Os crimes organizados que não têm fronteiras são verificados em vários Estados da Federação; todavia, a maioria concentrada na cidade do Rio de Janeiro motivados pelo tráfico de drogas, cujas vias de trânsito desta cidade - apelidadas ou conhecidas como Linhas Vermelha e/ou Amarela - nesse contexto se tornaram semelhantes à Faixa de Gaza, no Oriente Médio. Por último, o Brasil supera mortes de países em guerra: 525 mil.

O tráfico de drogas é violento com cerca de aproximadamente 2,5 milhões de dependentes químicos. O cômputo se refere somente ao vício do crack, droga semissintética e muitos desses usuários são obesos; inacreditavelmente, no intuito de emagrecimento, quadro estatístico demonstra o envolvimento significativo de mulheres, segundo pesquisadora da Universidade de São Paulo. O uso da droga para emagrecer é caso social a ser imediatamente combatido pelos órgãos médico-assistenciais do País. Enquanto houver consumo, haverá narcotráfico. A Polícia Federal trabalha exaustivamente ao combate do narcotráfico e agora mais fortalecida com a inauguração do Centro de Cooperação Internacional, com sede no Rio de Janeiro, que integra composição de 55 outros países. Todavia quem sustenta o tráfico de drogas é o próprio tráfico, por meio de novas drogas sintéticas e sofisticada tecnologia.

5.4. O Estatuto do Desarmamento, Lei n. 10.826, de 22 de dezembro de 2003, é muito pouco observado em seus capítulos I (Do Sistema Nacional de Armas); II (Do Registro); III (Do Porte); IV (Dos Crimes das Pessoas). Enfatizando o art. 17 que reza sobre o comércio ilegal de armas de fogo. Em intermédio, o Decreto n. 5.123, de 1 de julho de 2004, publicado no Diário Oficial da União, em 2 de julho de 2004, aborda no Capítulo I "Dos Sistemas de Controle de Armas de Fogo” e demais Capítulos, Seções e Subseções, os quais todo brasileiro deveria, atenciosamente, lê-los.

Em levantamento da Ouvidoria das Polícias do Estado de São Paulo revelase que 101 crianças e adolescentes foram mortos entre os anos 2010/2016 em possíveis confrontos, sendo uma criança de 10 anos de idade, uma de 13 anos e oito de 14 anos; os demais, acima de 15 anos.

5.5. Cerca de 44 mil pessoas morrem no trânsito anualmente, mortes causadas por condutores embriagados, cujo resultado é qualificado como objeto de dolo 
eventual e multa. E o delituoso atinge a liberdade. Os acidentes acarretam prejuízo aos governos em índice de $2 \%$ do Produto Interno Bruto (PIB). O Ministério Público Federal (MPF) tem reivindicado maior rigorosidade aos ditames do Código de Trânsito Brasileiro (CTB), Lei $n$. 9.503, de 23 de setembro de 1997.

O MPF é composto de nova e eficiente geração. A Operação Lava-Jato, por exemplo, é comandada na capital do Paraná, Curitiba, pelo juiz Sérgio Moro, protagonizando o episódio mais eficiente na História da Democracia brasileira. O magistrado foi premiado pelo Povo brasileiro, inclusive na alta escala política dos EUA. Ele analisa processos aos moldes do magistrado italiano Antonio Di Pietro intitulada Operação Mãos Limpas (1992-1994) em combate à corrupção na cidade de Milão, Itália, apurada e concluída com 3,5 mil presos políticos. No Supremo Tribunal Federal, a Operação Lava-Jato tem a coordenação nos relatórios a ela destinados pelo ministro Teori Zavascki.

Em parâmetro ao Governo da presidente afastada, Dilma Rousseff, o Governo interino de Michel Temer respalda com mais precisão o desenrolar da Operação Lava-Jato; enfatiza-se o Ministério da Justiça na Gestão do ministro Alexandre de Moraes, desta Academia de Direito da Universidade de São Paulo (FDUSP). O histórico completo da Operação Lava-Jato está narrado com minúcias no livro que leva o mesmo nome, Lava-Jato, de autoria do jornalista Vladimir Netto.

Enfim, todos somos uma biografia a ser escrita: o juiz de primeira instância Sérgio Moro preencheu requisitos do que é justo, representado na Mitologia grega Aletheia brasileira -, ou seja, a busca da verdade! O sistema democrático brasileiro jamais poderá impedir o avanço da Operação Lava-Jato nas análises de processos investigativos, porque além de colaborar para o fortalecimento da eliminação da corrupção, passou a ter vida própria. O País está no caminho do "passar a limpo"; Saty = verdade e Agaha = firmeza, lembrando Mahatma Gandhi que usava a expressão "Satyagaha", apelido, inclusive, de um dos desdobramentos da Operação Lava-Jato. Anseia-se pela verdade e pela firmeza do Estado brasileiro. A premissa final é a de que todos somos iguais perante a Lei brasileira, uma vez assim devemos ser tratados. Louva-se também o quadro de procuradores das duas esferas como os delegados curitibanos da Polícia Federal.

Há um lado curioso favorável ao quadro cultural nesta Operação: mais de 400 obras de arte foram apreendidas e/ou confiscadas, adquiridas por meio de propina pelos corruptos, as quais se encontram em exposição no Museu Oscar Niemayer, de Curitiba. As obras de arte estão sendo analisadas por peritos sobre a autenticidade, principalmente as de óleo sobre tela, configuradas como $O S T$. É tão vasta a extensão do número de políticos e empresários que se submeteram às delações premiadas e de acordos de leniência que se generalizou, no País, chamá-la de Bíblia dos Escândalos, com seus seiscentos e sessenta e seis casos de busca e apreensão, até esta data. Premissa final: urgência imediata no âmbito 
da reforma política no País, cujos brasileiros, estupefatos, nunca tinham visto tamanha quadrilha em ação ... em tempos de crise! E assim, a atividade econômica brasileira tem sofrido alta retração, segundo o Banco Central.

5.6. Quanto ao direito à Saúde, a maioria dos hospitais se encontra em total falência junto aos convênios de planos de Saúde; inclui-se no breve cômputo o cenário desolador de cerca de 4 mil casos de microcefalia - geração portadora de má formação cerebral -, em todo o País, causado pelo zika vírus, conhecido grupo de arbovírus, de origem africana, o mesmo da dengue, chicungunya, transmitidos pelo aedes aegypti, cujo mosquito vetor, com expansão por toda a América Latina e Caribe - exceto Canadá e Chile pela baixa imunidade -, é alerta da Organização Mundial de Saúde (OMS).

[O zika vírus acarreta má formação congênita aos recém-nascidos, ultrapassando a placenta das mulheres grávidas e atingindo o feto em formação, segundo a Fundação Osvaldo Cruz (Fiocruz), um dos institutos de pesquisas científicas à frente ao combate ao vírus. O Instituto Butantan recebeu cerca de US\$ 3 milhões dos EUA para o desenvolvimento da vacina contra o zika vírus.] Entretanto, a Agência Nacional de Vigilância Sanitária (Anvisa) anuncia que está prestes a liberar vacina - elaborada por laboratório de pesquisa científica da França - de imunização contra os quatro tipos de doença causados pelo arbovírus.

Computa-se, por fim, a crescente e contínua agressão aos profissionais do Sistema Único de Saúde (SUS), cujo motivo apontado é a precária assistência ocorrida em hospitais da rede pública. Não se olvida o erro médico que chega a $82 \%$ em denúncias sendo que o Supremo Tribunal de Justiça recebe cerca de 500 casos denunciantes que estão sendo discutidos em ações judiciais.

5.7. Especialistas em gerenciamento de risco reivindicam legislação nacional à pauta específica, incêndio, ao encontro da tragédia da Boate Kiss, em Santa Maria, Rio Grande do Sul, RS, em 27 de janeiro de 2013, quando morreram 242 jovens intoxicados e pisoteados, provocando comoção aos brasileiros. Os familiares dos falecidos recorreram à Corte Interamericana dos Direitos Humanos, com sede nos EUA, motivados pelo atraso nas investigações, indenizações e à não-punição aos responsáveis, incluso agentes públicos.

5.8. O Brasil é um tesouro em paisagens das mais belas de todo o planeta, a exemplo das notas da partitura de Ary Barroso em Aquarela do Brasil que, inclusive, precisam ser preservadas com total rigorosidade; a mostra da beleza vem dos quatro nortes do território, enfatizando as do Nordeste, cantadas por Rachel de Queiroz, nascida no Ceará e Autora de obras literárias compostas e recheadas de textos românticos e poéticos, narrando, assim, a magia das terras brasileiras e o seu enriquecimento.

Dentre elas, o clássico $O$ Quinze, no qual descreve a tragédia da seca, na região nordestina, em 1915. Aos protetores de animais, Vidas Secas, de Graciliano 
Ramos, obra que possui, dentre os personagens, a história da cadela Baleia; aplaudido o Autor tanto na Literatura quanto em festivais do Cinema Internacional. A caatinga é um bioma exclusivamente brasileiro, além de bela apenas $1 \%$ da área é protegida; senão se aplicar imediata sustentabilidade à proteção, segundo cientistas, o alerta é o do seu desaparecimento. Incluso a extinção de animais exóticos que lá habitam como o lobo guará; uma fauna que enriquece o planeta!

Entremeio, a arquitetura brasileira contempla mais de vinte pontuações ditadas pela Unesco, a exemplo de Brasília e recentemente - por meio da própria Unesco o Conjunto Arquitetônico da Pampulha, Minas Gerais. Na visita à Igreja de São Francisco de Assis ou à Casa do Baile, o orgulho de ser brasileiro. O cenário mineiro inspirou Oscar Niemayer, na década de 40, abusar de suas curvas e a se imortalizar, mudando a arquitetura nacional. É o arquiteto mais aplaudido pela sua imensa e magnífica obra. São deveres incluir o paisagismo de Roberto Burle Marx e as pinturas de Di Cavalcanti.

No painel artístico arquitetônico, os centros históricos de São Luís - repletos de azulejos portugueses em paredes dos casarões coloniais e nas calçadas -, Congonhas/ Diamantina/Tiradentes [que leva o nome a homenagear Joaquim José da Silva Xavier, um dentista que lutou pela independência do País durante a Monarquia; o mártir protagonizou o episódio batizado de Inconfidência Mineira]. As cidades reúnem parte das obras de Aleijadinho talhadas em pedra-sabão. Ouro Preto, Olinda, Salvador e Goiás são cidades que guardam séculos de História e necessitam da educação patrimonial, significado de preservação. Evidências físicas para se admirar no decorrer dos séculos!

5.9. Uma das funções atuais do Direito é a de impulsionar novos comportamentos sociais diante de um mundo em constante mudança. Existe uma vulnerabilidade a ser protegida: a Natureza quanto à cultura da população tradicional estar ameaçada devido à evolução e expansão da economia, deste século XXI.

$\mathrm{Na}$ Política, dentre os caminhos a se fortalecer é o de maior diálogo com a população amadurecida tecnicamente informatizada e centrais sindicais; resultados promissores ao equilíbrio socioeconômico. A unificação de pensamentos na Câmara Federal é destaque à política homogeneizada. Os mais de trinta partidos políticos perderam a performance de atuar entre a Política e a representação eleitoral. Apesar da crise, o País é respeitado pela Democracia e pelo futuro porvir contemplando esse povo da Terra Dourada, onde mora o Cristo Redentor, patrimônio da Humanidade, que recebe os turistas de braços paternos abertos. O Brasil é a nossa casa!

Esses são os tempos modernos que filósofos denominam Era das Massas, na medida em que os homens sentem medo e a necessidade de se sentirem seguros. O Brasil, junto à Política e ao Direito brasileiro, necessita de inovações! A premissa final: Educação que deve estar na escala da prioridade social. 
O assessoramento da Igreja católica sempre estará presente - sob o comando de um líder espiritual mundial -, entidade política, econômica e respeitada na concepção e tradição do Povo brasileiro. A entidade conduz a Humanidade há séculos, por meio da Lei do Amor, trazendo, por sua vez, pacifismo, respeito, confiança, indiscriminação e paz em época de pós-globalização.

São Paulo, fevereiro de 2016. Atualizado em julho de 2016.

\section{Referências}

ARMSTRONG, Karen. Em nome de Deus: o fundamentalismo no judaísmo, no cristianismo e no islamismo. Tradução de Hildegard Feist. São Paulo: Comanhia das Letras, 2001.

BITTAR, Eduardo Carlos Bianca. Curso de ética jurídica: ética geral e profissional. 8. ed. São Paulo: Saraiva, 2011.

BLOCK, Marc. A sociedade feudal. Rio de Janeiro: Editora Melhoramentos, 2000.

BRITTO POLETTI, Ronaldo Rebelo de (Dir.). Notícia do direito brasileiro. Nova Séria ns. 15 e 16. Brasília: UnB, 2010.

CAMPOS NETO, Antonio Augusto Machado de. O cristianismo. O direito canônico. Revista da Faculdade de Direito, Universidade de São Paulo, São Paulo, v. 105, p. 39-77, jan./dez. 2010.

CAMPOS NETO, Antonio Augusto Machado de. O judaísmo. O direito talmúdico. Revista da Faculdade de Direito, Universidade de São Paulo, São Paulo, v. 103, p. 27-67, jan./dez. 2008.

COÊLHO, Sacha Calmon Navarro. A história da mitologia judaico-cristã: uma teoria sobre as religiões reveladas e servidas por uma antologia comentada de autores seletos. São Paulo: Noeses, 2010 .

CROWLEY, Roger. 1453: a guerra santa por Constantinopla e o confronto entre o Islã e o Ocidente. Tradução do prof. Rogério Bettoni. São Paulo: Rosari, 2009.

DEL VECCHIO, Giorgio. Lições de filosofia do direito. Tradução de António José Brandão. 5. ed. Coimbra: Armênio Amado, 1977.

DEMANT, Peter. O mundo muçulmano. São Paulo: Contexto, 2008.

DULLES, John W. F. A Faculdade de Direito de São Paulo e a resistência anti-Vargas (1938-1945). Rio de Janeiro: Nova Fronteira, 1984.

FERREIRA, Aurélio Buarque de Holanda. Novo dicionário Aurélio da língua portuguesa. Rio de Janeiro: Nova Fronteira, 2013.

GABEIRA, Fernando. O que é isso, companheiro? Rio de Janeiro: Codecri, 1980.

GHIRLANDA, Gianfranco. Il Diritto nel mistero della chiesa. Roma: Editora I Romani, 1985/86. 
GILISSEN, John. Introdução histórica ao direito. Tradução A. M. Hespanha, L. M. Macaísta Malheiros. Lisboa: Fundação Calouste Gulbenkian, 1995.

GOMES, Laurentino. 1822: como um homem sábio, uma princesa triste e um escocês louco por dinheiro ajudaram D. Pedro a criar o Brsial - um país que tinha tudo para dar errado: Rio de Janeiro: Nova Fronteira, 2010.

HAYEK, Samir El. Alcorão sagrado. São Paulo: Tangará, 1975.

HILL, Jonathan. História do Cristianismo. Tradução de Rachel Kopit Cunha, Juliana A. Saad e Marcos Capono; 1. ed., impresso e acabado em Cingapura. São Paulo: Rosari, 2008.

JUSTINIANO I [Flavius Petrus Sabbatius Justinianus]. Institutas do Imperador Justiniano: manual didático para uso dos estudantes de direito de Constantinopla, elaborado por ordem do Imperador Justiniano, no ano de 533 d.C. Tradução J. Cretella Jr. e Agnes Cretella. 2. ed., ampl. e rev. da tradução. São Paulo: Revista dos Tribunais, 2005.

KAUTSKY, Karl. A origem do cristianismo. Tradução, introdução, apêndice e notas de Luiz Alberto Moniz Bandeira. Rio de Janeiro: Civilização Brasileira, 2010.

KELSEN, Hans. A ilusão da justiça. Tradução Sérgio Tellaroli. São Paulo: Martins Fontes, 1995.

KELSEN, Hans. Teoria pura do direito. Tradução João Baptista Machado. São Paulo: Martins Fontes, 1995.

MARTINS, Ana Luiza; BARBUY, Heloisa. Arcadas: história da Faculdade de Direito do Largo de São Francisco, 1827-1997. São Paulo: BM\&F: Alternativa, 1999.

MELAMED, Meir Matzliah. Torá: a Lei de Moisés. Edição revisada e ampliada da obra A Lei de Moisés e as Haftarót. Tradução, explicações e comentários do rabino Meir Matzliah Melamed. São Paulo: Sêfer, 2001.

MICHAELIS. Ilustrated Dictionary English-Portuguese. São Paulo: Editora Melhoramentos, 2010.

PAES FILHO, Orlando. Angus: as Cruzadas. São Paulo: Planeta, 2005.

QUADROS NETO, Jânio; GUALAZZI, Eduardo Lobo Botelho. Jânio Quadros: memorial à história do Brasil. São Paulo: Rideel, 1996.

SFORZA, Conde Carlo. O pensamento vivo de Maquiavel. Tradução de Rubens Gomes de Souza. São Paulo: Livraria Martins Fontes, [195-?].

TELLES JÚNIOR, Goffredo da Silva. A criação do direito. 2. ed., rev. São Paulo: Ed. Juarez de Oliveira, 2004.

TELLES JÚNIOR, Goffredo da Silva. A folha dobrada: lembranças de um estudante. Rio de Janeiro: Nova Fronteira, 1999.

WILKINSON, Philip. O livro ilustrado das religiões. O fascinante universo das crenças e doutrinas que acompanham o homem através dos tempos. São Paulo: PubliFolha, 2000. 
